\title{
Optical Biosensors for Diagnostics of Infectious Viral Disease: A Recent Update
}

\author{
Atul Sharma ${ }^{1}{ }^{\oplus}$, Rupesh Kumar Mishra ${ }^{2,3, *}$, K. Yugender Goud $^{4, *}\left(\mathbb{D}\right.$, Mona A. Mohamed ${ }^{5}{ }^{\oplus}$, Shekher Kummari ${ }^{6}$, \\ Swapnil Tiwari ${ }^{7}{ }^{\circ}$, Zhanhong Li $^{8}{ }^{8}$, Roger Narayan ${ }^{9,10}{ }^{\oplus}$, Lia A. Stanciu ${ }^{3, *}$ and Jean Louis Marty ${ }^{11, *}$
}

1 Department of Pharmaceutical Chemistry, SGT College of Pharmacy, SGT University, Budhera, Gurugram 122505, Haryana, India; atul_fphs@sgtuniversity.org

2 Bindley Bio-Science Center, Lab 222, 1203 W. State St., Purdue University, West Lafayette, IN 47907, USA

3 School of Materials Engineering, Purdue University, 701 West Stadium Avenue, West Lafayette, IN 47907, USA

4 Department of NanoEngineering, University of California San Diego, La Jolla, CA 92093, USA

5 Pharmaceutical Chemistry Department, National Organization for Drug Control and Research (NODCAR), Egyptian Drug Authority, Giza 99999, Egypt; mona7722@aucegypt.edu

6 Department of Chemistry, National Institute of Technology, Warangal 506004, Telangana, India; shekharkummari@nitw.ac.in

7 School of Studies in Chemistry, Pt. Ravishankar Shukla University, Raipur 492010, Chattisgarh, India; swapnil.tiwari7@gmail.com

8 School of Medical Instrument and Food Engineering, University of Shanghai for Science and Technology, 516 Jungong Road, Yangpu District, Shanghai 200093, China; zhli@sspu.edu.cn

check for updates

Citation: Sharma, A.; Mishra, R.K.; Goud, K.Y.; Mohamed, M.A.;

Kummari, S.; Tiwari, S.; Li, Z.;

Narayan, R.; Stanciu, L.A.; Marty, J.L. Optical Biosensors for Diagnostics of Infectious Viral Disease: A Recent Update. Diagnostics 2021, 11, 2083. https://doi.org/10.3390/

diagnostics11112083

Academic Editor: Jeroen Lammertyn

Received: 26 September 2021

Accepted: 5 November 2021

Published: 10 November 2021

Publisher's Note: MDPI stays neutral with regard to jurisdictional claims in published maps and institutional affiliations.

\section{Copyright: (c) 2021 by the authors.} Licensee MDPI, Basel, Switzerland. This article is an open access article distributed under the terms and conditions of the Creative Commons Attribution (CC BY) license (https:// creativecommons.org/licenses/by/ $4.0 /)$.
9 Department of Materials Science and Engineering, NC State University, Raleigh, NC 27695, USA; rjnaraya@ncsu.edu

10 Joint Department of Biomedical Engineering, North Carolina State University, Raleigh, NC 27695, USA

11 BAE-LBBM Laboratory, University of Perpignan via Domitia, 52 Avenue Paul Alduy, CEDEX 9 , 66860 Perpignan, France

* Correspondence: rkmishra@purdue.edu (R.K.M.); ykotagiri@eng.ucsd.edu (K.Y.G.); lstanciu@purdue.edu (L.A.S.); jlmarty@univ-perp.fr (J.L.M.)

Abstract: The design and development of biosensors, analytical devices used to detect various analytes in different matrices, has emerged. Biosensors indicate a biorecognition element with a physicochemical analyzer or detector, i.e., a transducer. In the present scenario, various types of biosensors have been deployed in healthcare and clinical research, for instance, biosensors for blood glucose monitoring. Pathogenic microbes are contributing mediators of numerous infectious diseases that are becoming extremely serious worldwide. The recent outbreak of COVID-19 is one of the most recent examples of such communal and deadly diseases. In efforts to work towards the efficacious treatment of pathogenic viral contagions, a fast and precise detection method is of the utmost importance in biomedical and healthcare sectors for early diagnostics and timely countermeasures. Among various available sensor systems, optical biosensors offer easy-to-use, fast, portable, handy, multiplexed, direct, real-time, and inexpensive diagnosis with the added advantages of specificity and sensitivity. Many progressive concepts and extremely multidisciplinary approaches, including microelectronics, microelectromechanical systems (MEMSs), nanotechnologies, molecular biology, and biotechnology with chemistry, are used to operate optical biosensors. A portable and handheld optical biosensing device would provide fast and reliable results for the identification and quantitation of pathogenic virus particles in each sample. In the modern day, the integration of intelligent nanomaterials in the developed devices provides much more sensitive and highly advanced sensors that may produce the results in no time and eventually help clinicians and doctors enormously. This review accentuates the existing challenges engaged in converting laboratory research to real-world device applications and optical diagnostics methods for virus infections. The review's background and progress are expected to be insightful to the researchers in the sensor field and facilitate the design and fabrication of optical sensors for life-threatening viruses with broader applicability to any desired pathogens.

Keywords: viral disease; optical biosensors; diagnostics; nanomaterial; fluorescence; SARS-CoV-2 


\section{Introduction}

A virus is a microscopic parasite and is the most minor transmittable agent, usually much smaller than bacteria. Viruses lack the capacity to survive and replicate outside of a host body [1,2]. They have been the cause of several diseases, such as Japanese encephalitis, Chikungunya, dengue, Ebola, influenza, hepatitis, flu, chicken pox, AIDS, severe acute respiratory syndrome (SARS), and several others [3,4]. A transportable viral particle comprises nucleic acids and an external shell of proteins. The most well-studied viruses have either RNA or DNA as genetic material to encrypt proteins [5]. These viruses are capable of fast replication and distribution and cause diseases, and hence, become a severe threat to human health. Viruses enter the host body and use their machinery for metabolism and self-replication [6]. Viruses have the ability to transmute quickly, along with a complicated exchange amid diverse aspects such as the universal movement of animals/humans and environmental factors contributing to the development of transmissible diseases [7]. Therefore, a specific analytical method is paramount for early virus screening and analysis [8]. A recent example of viral infection is the COVID-19 pandemic, which has already caused the death of more than 3.5 million people worldwide $[9,10]$. In the literature, various methods for detecting and identifying viruses have been documented, including microbiological and biochemical testing, genetic engineering methods, and immunological procedures $[10,11]$.

Conventional viral detection methods include an enzyme-based antibody assay and a polymerase chain reaction (PCR)based qualitative assay, viral separation, and immunofluorescence based on microscopy, which is not suitable for repetitive clinical testing [12,13]. These techniques necessitate a long turnaround time (2 to 14 days), which is inadequate for combatting rapid community spread. The costs of current viral detection tests are also high. Therefore, rapid, reliable, and reproducible diagnostic methods are vital and "the need of the hour" to recognize pathogenic agents in patients' biological fluids [14]. Biosensors hold considerable promise as an alternate analytical tool to the existing methods for viral detection, which can help provide timely detection and intervention $[15,16]$.

Optical biosensors have been developed for many years in diverse fields. Over the past decade, movement within the arena of optical biosensor development has been fast-paced, and numerous optical biosensing platforms have been explored for sensitive and label-free detection; these include, but are not limited to, surface plasmon resonance [17-19], interferometers [20], ring-resonators [21], photonic crystals [22-24], fiber-optics [17,25], and planar optical waveguides [26,27]. The advantages of optical sensors include immunity to electromagnetic interference, remote sensing ability, miniaturization of the assays, intrinsic safety, and the ability to offer multiplexed recognition within a single device [28]. One of the most substantial downsides of regularly used optical sensing methods is the permeation depth of the evanescent field, which is usually less significant than the average size of a bacterial cell, stemming from the incapability to sense higher particulate antigens with sufficient sensitivity [29]. Countless of the current techniques also involve expensive instrumentation to convey the signal read-out. In turn, optical biosensors have been developed to investigate numerous analytes such as proteins, nucleic acid, bacteria, biomarkers, and environmental contaminants, to only name a few [30-35]. Optical biosensors are known to be extremely sensitive and can offer ultra-low detection levels, a linear output, low-power consumption, and high resolution [36,37]. Furthermore, they offer excellent repeatability, accuracy, and the ability to be miniaturized. In this work, we will present an overview of viral infectious diseases and their biomarkers, a discussion of recent literature on optical biosensors for viral diagnostics, and a summary of the current state of the art of the field.

\section{Viral Infectious Diseases}

\subsection{COVID-19}

Coronaviruses are a large class of viruses, and their occurrences are common in people [38]. They also known to cause various illnesses, from the common cold to severe acute 
respiratory syndrome (SARS) [39]. The severe acute respiratory syndrome coronavirus 2 (SARS-CoV-2) causes COVID-19, as it is now called, and is rapidly spreading from its origin in Wuhan City of the Hubei Province in China to the rest of the world [16]. Globally, approximately 167.5 million cases of COVID-19 and approximately 3.5 million deaths have been reported as of 25 May 2021 [9]. For instance, about 27.16 million confirmed cases and 0.31 million deaths have been reported in India [9]. The WHO announced COVID-19 to be a pandemic disease on 11 March 2020 [40,41]. Initially, during the Covid-19 outbreak no effective treatment strategy was formulated; hence, countries were dependent on social distancing, wearing masks, and lockdowns [42,43]. Fever, dry cough, weariness, and muscle soreness are among the symptoms of this condition, which also includes headache, lymphopenia, and dyspnea. Some people also experience nausea, constipation, and diarrhea-like conditions after 2-3 days [16,44]. Elderly people and those who have chronic diseases such as asthma, diabetes, or hypertension seem to be at higher risk for developing severe complications from COVID-19 infection [45], while the disease has a mild effect in children [46,47].

The biosensor is a capable diagnostic tool that appears to be an alternative to many existing analytical methods. Recently, an optical microfluidic chip-based biosensor was developed to detect antibodies against SARS-CoV-2 spike protein [48]. The sensing mechanism relies on the localized surface plasmon resonance (LSPR) involving gold nanospikes (fabricated by electrodeposition) in a microfluidic device coupled with an optical probe. The developed sensing platform achieved a detection level down to $0.5 \mathrm{pM}$ in $30 \mathrm{~min}$. The diagnostic platform showed great potential to supplement current serological assays and improve COVID-19 diagnosis. In other reported work, Ashab Uddin et al.; proposed a surface plasmon resonance (SPR) structure based on the Kretschmann configuration incorporating layers of silicon and $\mathrm{BaTiO}_{3}$ on top of $\mathrm{Ag}$ for real-time detection of SARSCoV-2 using thiol-tethered DNA as a ligand [49]. This study performed an extensive numerical analysis based on transfer matrix theory. About a 7.6 times enhanced sensitivity was obtained using the proposed architecture for SARS-CoV-2 detection compared to the basic Kretschmann configuration. Consequently, the proposed sensor design provided an appropriate pattern for highly sensitive, swift, and noninvasive biosensing, which could be beneficial if implemented in experimental sensing protocols.

Meanwhile, Murugan et al. (2020) described a plasmonic fiber-optic (P-FAB) platform for one-step, wash-free detection of SARS-CoV-2 virus particles in saliva samples with minimal sample pre-processing [50]. The P-FAB, which is based on a U-bent optical fiber sensor system, is a handy and sensitive diagnostic platform that has been used to detect a variety of biomolecular analytes for a long time. The two plasmonic, labeled and label-free immunoassays suggested here on the susceptible P-FAB platform could be a good option for diagnosing $10^{6}$ particles/mL COVID-19 in $15 \mathrm{~min}$.

\subsection{Middle East Respiratory Syndrome (MERS)}

MERS is a viral respiratory disease caused by a novel coronavirus (Middle East respiratory syndrome coronavirus, or MERS-CoV) initially detected in Saudi Arabia in 2012 [51,52]. Fever, cough, and shortness of breath are common MERS symptoms. Pneumonia is a frequent ailment; however, it is not always present [51]. Symptoms of the gastrointestinal tract, such as diarrhoea, have also been observed. Most of these asymptomatic infections were discovered after a thorough contact tracing of a laboratory-confirmed case. However, some laboratory-confirmed MERS-CoV infections are described as asymptomatic, which means they have no clinical symptoms [53]. Despite this, a laboratory test revealed that the cause of death for $35 \%$ of patients who have died was MERS-CoV [54]. In the literature, the development of several biosensors have been written for MERS detection [55-57]. For instance, MERS-CoV was specifically detected using a label-free colorimetric assay by employing gold nanoparticles. Colorimetric tests are a representative tool used to easily classify the target analyte in the matrix via color changes of an indicator. 
Kim et al. proposed a colorimetric test relying on an expanded form of doublestranded DNA (dsDNA) self-assembly shielded gold nanoparticles (AuNPs) under an electrolyte-rich medium to detect MERS-CoV [58]. A localized surface Plasmon resonance shift and color variations of AuNPs in the UV-vis wavelength range could be used to validate the presence of viral molecules on this platform. The authors created a pair of thiol-modified probes with complementary base pairs upstream of the E protein gene (upE) and open reading frames (ORF) $1 \mathrm{a}$ on MERS-CoV at either the $5^{\prime}$ or $3^{\prime}$ end. The disulfideinduced extended self-assembled complex formed by the target and probes' dsDNA shields AuNPs against salt-induced aggregation and optical property transition. This colorimetric assay was able to distinguish $30 \mathrm{bp}$ MERS-CoV at $1.0 \mathrm{pmol} \mathrm{L}^{-1}$. In another approach, a multiplexed paper-based colorimetric DNA sensor was developed using pyrrolidinyl peptide nucleic acid-induced AgNPs aggregation for the detection of MERS-CoV [59]. By monitoring the color change of AgNPs, the oligonucleotide target was found, with detection limits of $1.53 \mathrm{nM}$ for MERS-CoV. The acpcPNA probe demonstrated significant selectivity for complementary oligonucleotides over single-base mismatch, two-base mismatch, and noncomplementary DNA targets in this research.

\subsection{Human Immunodeficiency Virus (HIV)}

Around 1920, the human immunodeficiency virus arrived in the Congo by crossing species from chimps to humans [60]. After an infection, acquired immunodeficiency syndrome develops, resulting in increasing immune weakness and life-threatening opportunistic infections [61]. HIV infects T cells that have a vital role in immunity [62]. The nuclear material of HIV comprises two copies of single-stranded RNA transcribed into double-stranded DNA by a complex reverse transcription process [63]. Nearly 37.9 million people have caught an HIV infection worldwide in 2018, and approximately 770,000 people had died due to HIV infection [64]. Identifying biomarkers and viruses in biological matrices has broad applications in early disease diagnostics and treatment monitoring. Shafiee et al. [65] utilized nanostructured photonic crystals (PC) to capture and analyze intact HIV1 viruses from biological samples. Researchers have also demonstrated a label-free and optical sensing technique. Upon irradiation with a broadband light source, the surface of the developed PC biosensor resonantly reflects a narrow wavelength band. The biological target adsorbs on the transducer surface, causing a shift in the resonant peak wavelength value (PWV) that can be detected with a wavelength resolution of $10 \mathrm{pm}$, allowing the identification of both biomolecular layers and a small number of viruses that are sparsely populated on the surface. The scientists were able to successfully collect and detect HIV-1 in serum and buffer samples with viral loads ranging from $10^{4}$ to $10^{8}$ copies $\mathrm{mL}^{-1}$. Diagnosis of HIV through a non-invasive route can be a significant way to diminish death [66].

\subsection{Hepatitis}

Hepatitis is inflammation of the liver. The disorder can be self-limiting or lead to fibrosis (scarring), cirrhosis, and liver cancer [67]. Hepatitis viruses most commonly cause hepatitis, although it can also be caused by other infections, toxic substances (such as alcohol and some medicines) [68], and autoimmune illnesses [69,70]. Hepatitis viruses are classified into five types: A, B, C, D, and E [68]. Because of the load of illness and death they inflict, as well as the potential for outbreaks and epidemic spread, these five categories are the most concerning [71]. Types B and C cause chronic disease in millions of people and are the leading cause of cirrhosis and cancer in the liver. Ingestion of contaminated food or water is the most common cause of hepatitis A and E [72]. Epidemics related to contaminated food or water can erupt explosively, such as the Shanghai (1988) epidemic that affected about 300,000 people [73]. Hepatitis B, C, and D usually occur because of parenteral contact with infected body fluids [74]. Hepatitis B transmission from the mother to baby at birth, from family member to child, and sexual contact are all common means of transmission for these viruses [75]. Jaundice (yellowing of the skin and eyes), black urine, intense exhaustion, nausea, vomiting, and abdominal pain are signs of an acute 
infection [76]. Hepatitis A is always a short-term, acute infection, but hepatitis B, C, and D are more likely to become chronic and persistent. Hepatitis B is spread by encountering infected blood samples, exchanging infected razors or dentist tools, and so on [77]. The hepatitis B virus has infected over 2 billion individuals worldwide (one out of three people). Every year, 30 million people become infected from the virus. Based on the evidence, nearly 292 million people are infected on a long-term basis [78]. More than 850,000 people die each year due to complications of hepatitis B infection, such as liver cirrhosis and carcinoma. Globally, an estimated 71 million people are infected with the chronic hepatitis $\mathrm{C}$ virus [79]. The hepatitis C virus causes hepatitis C (HCV) [80]. Hepatitis C is spread through direct contact with contaminated bodily fluids, most commonly through injectable drugs [79]. In the United States, HCV is one of the most frequent blood-borne viral infections [81]. Hepatitis D, called delta hepatitis, is a severe liver disease caused by the hepatitis D virus (HDV) [82]. HDV is contracted through direct contact with infected blood [83] and propagates hepatitis B infection [84]. An optical fluorescence-based assay was developed to detect hepatitis $C$ viral DNA with high sensitivity and selectivity [85]. A low-cost $\delta$-FeOOH nanosheet was used as the novel fluorescent quencher. The dye-labeled ssDNA probe was quenched by $\delta$-FeOOH nanosheets by fluorescence resonance energy transfer due to the solid binding capability between the single-strand DNA (ssDNA) and the $\delta$-FeOOH nanosheets (FRET). The target DNA and dye-labeled ssDNA probe would then form a double-stranded DNA complex (dsDNA) after the target DNA was added. Due to the weak bind affinity between the short fragments and $\delta$-FeOOH nanosheets, the dye-labeled ssDNA probe in the dsDNA complex was sequentially analyzed into short fragments from the $3^{\prime}$-terminus by Exonuclease III, and the fluorescence signal was recovered. By exploiting these nanosheets and integrating them with exonuclease III-assisted target-recycling signal amplification, the limit of detection was improved to $10 \mathrm{pM}$ [85].

\subsection{Dengue}

Mosquitoes transmit dengue virus (DENV) infection [86]; dengue virus is a single enveloped positive-stranded RNA virus with five serotypes [87]. Half of the world's population is infected by DENV. Nearly 3 billion people are infected [88]. About 400 million people are infected yearly with DENV. Approximately 100 million people get sick from infection, and 22,000 die from dengue complications [89,90]. Avian influenza viruses can infect birds and humans. The transmission of disease occurs through contact with sick birds [91]. It can also be transmitted from an infected human to others [92]. Symptoms are very similar to the common cold, including fever, cough, sore throat, headache, muscle pain, and shortness of breath. Some antiviral drugs may be helpful if taken within two days of the appearance of symptoms [50].

Dengue E protein [93] detection based on a biofunctionalized tapered optical fiber (TOF)-based sensor with a polyamidoamine (PAMAM) dendrimer was created. The TOF dimension created an evanescent field that was sensitive to changes in the external medium, and incorporating PAMAM increased bio-recognition molecule adhesion and anti-DENV II E protein antibodies. As a result, more active sites for DENV II E protein absorption onto the tapering region were formed. With $K_{d}=1.02 \times 10^{-10} \mathrm{M}$, the sensor's resolution and detection limit were $19.53 \mathrm{~nm} / \mathrm{nM}$ and $1.0 \mathrm{pM}$, respectively. This research has presented promising potential to improve dengue diagnostics. A spin coating approach was used to create an immobilized monoclonal antibody (IgM) on gold/Fe-MPA-NCC-CTAB /EDCNHS thin film to detect DENV E protein [94]. Upon exposure to DENV E-protein, IgM immobilized gold/Fe-MPA-NCC-CTAB/EDC-NHS thin-film generated a SPR signal in the concentration ranges from 0.0001 to $10 \mathrm{nM}$. The developed method exhibited a linear relationship between SPR angle and concentration of DENV E-protein up to $0.01 \mathrm{nM}$, with a sensitivity of $39.96^{\circ} \mathrm{nM}^{-1}$. 


\subsection{Biomarkers}

Several biomarkers such as DNA, RNA, peptides, antibodies, glycoproteins, antigens, etc., can be utilized as an analyte of interest to detect viral infectious [95]. These biomarkers are classified as two significant categories: antigens and antibodies. Most of the stated viruses have either RNA or DNA as genetic material to encrypt proteins [5]. The viruses encompass three fundamental elements of precisely genetic material (DNA or RNA), nucleocapsid protein, and, lastly, capsid proteins. The hereditary substance is principally obscured with the encircle proteins known as nucleocapsid proteins, pursued by the wrapping of derivative envelope proteins, for instance, capsid protein. The virus admittance commences with the addition of cell-surface receptors and culminates with the release of the viral genome to the host cell cytoplasm [96]. Such access arises in two ways: endocytic and non-endocytic routes. The entire virus components, whether it is RNA, DNA, or nucleo/capsid proteins, will be instantly accessible when the virus penetrates the host cell. The B lymphocytes squirt the immunoglobulins in the body in reply to the virus antigen mechanisms. Therefore, the accessibility of the antigens (RNA or DNA, proteins) and corresponding antibodies in the neighboring cell renders it possible to distinguish by the optical biosensing methods by deploying suitable biomolecules [97-99]. Besides the viral diagnostics, examining the acuteness of the viral contamination is equally crucial to cure the ill person.

Due to their similar symptoms, one of the most prevalent medical challenges communities have faced is separating viral illnesses from bacterial infections, or vice versa. However, there is a $50 \%$ probability that viral infections will be misinterpreted as bacterial illnesses, necessitating antibiotic prescriptions to prevent the spread of life-threatening pathogenic germs [100]. Furthermore, an ideal biomarker must be independent of the length of febrile illness and comorbidities, as well as detectable qualities from minimally intrusive samples. The gravity of the viral disease can conceivably be evaluated by identifying other biomarkers such as interleukins, C-reactive protein, TNF- $\alpha$, glutamate, interferons, $\mathrm{D}$-dimer, and hematological biomarkers. Infection biomarkers can be categorized into therapeutic and pathogenetic biomarkers that play a critical role with clinical significance in diagnostics and prognostics. These biomarkers may well be measured by optical biosensing methods [101,102].

The majority of the studies are focused on identifying one or more host biomarkers that are produced as a result of the body's immunological responses to infections. The immune system of the host reacts to infection by releasing chemicals into the circulatory system that reflect real-time pathogenic changes in the body. Because of their involvement in a variety of disease processes, the concentrations of these compounds released into the bloodstream have biological importance and hence serve as target biomarkers [103]. However, not all of these molecules are appropriate for this purpose, and they must meet particular criteria. For example, polymorphonuclear leukocytes (PMN), human neutrophil lipocalin (HNL) [104], neutrophil counts, white blood cells (WBC), and erythrocyte sedimentation rate (ESR) $[103,104]$ are high-performing hematologic host biomarkers with statistically significant findings. PMNs, or phagocytes, have been found to be raised in the blood and are thought to play a key part in the host's defense response during an infection episode [105]. In the event of various etiological agents that stimulate immunity, these cells inherit diverse sets of information and, as a result, operate as disease biomarkers in specific infection contexts [106]. Inflammation indicators such as C-reactive protein (CRP) and procalcitonin (PCT) indicated statistically significant differences between bacterial and nonbacterial illnesses. In humans, CRP is a Ca-dependent ligand-binding plasma protein made up of cyclic homo-pentameric non-glycosylated polypeptide subunits [107], whereas PCT is a precursor of the hormone calcitonin released by the thyroid glands C cells [108]. They are now well recognized for acute and severe viral infections, as their level is a crucial criterion for inflammation. Cytokines, which are mediators of inflammatory responses to invading pathogens and act as infection biomarkers, are another family of host protein biomarkers. Pro-inflammatory cytokines, such as IL-1, IL-2, IL-6, IL-8, and TNF, as well 
as anti-inflammatory cytokines, such as IL-4, IL-10, and IL-13, can be divided into two categories [102,109]. Among all, the glycoprotein $(21 \mathrm{kDa})$ that makes up IL-6 is generated mostly by macrophages and lymphocytes. It is involved in lymphocyte and macrophage activation and accumulation, as well as the release of monocyte chemoattractant protein-1 (MCP-1) [110]. IL-6 levels have been found to be high in individuals with severe infection; therefore, it can be used as a disease indicator [111].

\section{Literature Overview (State of the Art)}

The influence of viruses on public health has had a significant impact on economic development in many countries. Thousands of people die every year from diseases involving a diverse variety of viruses around the world. In the last few decades, there have been growing concerns about their possible use in biological weapons [112-114]. Viruses can propagate quickly by natural means. Even though much is understood about viruses' biology and pathogenicity, the advent of new agents and viruses' ability to mutate rapidly will make them difficult to detect. Viruses remain enigmatic for a variety of reasons, making it impossible for physicians to recognize them quickly. A clinical diagnosis is difficult at this stage, and a confirmatory test is needed to identify the pathogen. Since the infecting agent may be several viruses or bacteria, a multiplexed test might be required to classify it accurately [115]. Fast, high-performance, and responsive virus identification are essential for an infected person to be adequately diagnosed and treated. The lack of adequate analysis tools and associated management interventions due to insufficient access to centralized and equipped health care facilities for diagnosis are the underlying causes of such severe diseases [116].

Significant problems for infectious disease control include the inappropriate usage of antimicrobials, the prevalence of multidrug-resistant (MDR) infections, the advent of novel infectious agents, and the speed at which disease spreads due to overpopulation and globalization [117]. A prompt diagnosis and implementation of selective antimicrobial therapy are crucial to effective infectious disease control. At the moment, a range of laboratory-based experiments, including microscopy, cultivation, immunoassays, and nucleic acid amplification, are used to diagnose clinically acute infectious diseases caused by bacterial, mycobacterial, virus, fungal, or parasite pathogens [117]. These in vitro diagnoses, though used extensively, have well-known weaknesses. In certain therapeutic cases, microscopy lacks precision, and culture has a considerable wait. Although highly responsive, immunoassays such as ELISA are labor-intensive and difficult to introduce. Nucleic acid amplification experiments, such as PCR, give molecular precision but have complicated sampling and false positives potential. The standard procedure flow to the common diagnosis of infectious diseases involves selecting and transferring biological samples from the treatment point to a central laboratory for expert sample analysis. Upon access to the findings (typically in days), the lab informs the physicians who contact the patients and modifies the procedure if required. This intrinsic inefficiency makes the provision of evidentiary treatment more complex at the right time and harms the use of antimicrobials [117].

A biosensor is an analytical tool that transforms molecular recognition of a target analyte to a measurable response through a transducer [118]. Biosensors are making a big difference by restructuring their sensing module for biomolecular detection, nanosized products, such as protein biomarkers and viruses, to convert the standard current analytical protocols into diagnostic strategies. Because of their high sensitivity to many well-known optical phenomena, such as surface plasmon, scattering, and interferometry, optical transducers are commonly used [119]. Optical biosensors, which can track and recognize chemical and biological organisms by calculating complete reflection as a recognizing signal (changes in absorbance, fluorescence, luminescence, polarization, and refractive index) with photodetectors, are important alternatives to conventional analytical techniques [120,121]. In comparison to other physicochemical transducers, SRP transducers have exciting features that allow for the monitoring of analytes in real-time without 
labeling. The immobilized bio transducer interacts with the analyte, causing a local rise in the metal surface refractive index to support an SPR signal change [122,123].

Current studies focus on developing methodologies for single-analyte, multi-analyte with smartphones and biochip microfluidic device integration [102]. Several optical biosensor systems for bacterial and viral biomarker detection have been developed, in which an immunosensor have been inserted into microfluidic platforms such as leukocytes from biological samples [124]. A biosensor-chip designed to caption the leucocytes of a biological specimen by antigen-antibody interactions is made from polydimethylsiloxane (PDMS), which is on a glass slide with thick microfluidic channels. The signal from the biochip is collected using a smartphone through fluorescent imaging and quantified using image processing software, which is appropriate for cell-limited resource biosensing infections [124]. A plethora of literature has already been published on monolithic integration for the detection of microbes [125-127].

Prilutsky et al. [116] presented an optical chemiluminescence-based assay to describe the functional activity of polymorphonuclear leukocytes (PMNs) or phagocytes. The reaction byproducts were examined using chemiluminescence (CL) measurements to quantify and localize respiratory burst generation. PMNs from the individuals with acute infections of the whole-blood system were subjected to this technique, which required luminol amplification for CL measurements. CL is thought to be a powerful means of exploring phagocytes' oxidative potential, and it may be evaluated as a luminol-dependent CL. This technique was used to identify viral or bacterial illnesses in origin using blood samples from 69 individuals with a fever $\left(>38^{\circ} \mathrm{C}\right)$.

Surface plasmon resonance (SPR) is the excitation of an electromagnetic wave that propagates by a certain angle of incident light beam through the interface of two media with dielectric constants of other signs, such as metal and a sample buffer [128,129]. The signal is dependent on absolute internal absorption, which causes the reflected light to have a lower intensity. Chen et al. were the first group to use a SPR biosensor for SARS-CoV morphological study [128]. SPR was capable of confirming that the $\mathrm{N}$-terminal removed proteinase dimer adopts a state unlike that of the full-length proteinase dimer [128].

Any change at the interface, such as changes in refractive index or the development of a nanoscale film thickness owing to surface molecule interactions, affects the angle at which the resonance occurs.

The resonance angle is vulnerable to some alteration at the interface, such as variations in refractive index or the forming of a nanoscale film thickness due to surface molecular interactions.

As a result, these shifts can be calculated by observing the minimum change of light intensity over time. Using T4 and BP14 bacteriophages as trapping components, a bioanalyzer based on SPR was used to detect Escherichia coli O157:H7 and methicillinresistant Staphylococcus aureus (MRSA) [130]. A SPR bioanalyzer could detect as few as $10^{3}$ $\mathrm{cfu} / \mathrm{mL}$ in less than $20 \mathrm{~min}$ without labeling or enrichment. Backscattering interferometry (BI) is another optical detection way applied for biosensing [131]. BI devices consist of a coherent single-wavelength light source, which focuses on a microfluidic canal and detectors to analyze reflected strength (commonly the low-power He-Ne or red diode laser). A strongly modulated interference pattern is generated due to sub-wavelength structures in the channel following a consistent laser illumination of the fluids-filled channel. The analysis of variations in the profile of fringe patterns by the detector positioned in the immediate backscatter direction aids in calculating refractive index changes and quantifying molecular binding events [117].

Kussrow et al. have revealed the importance of applying BI for quick detection of purified total human IgG from seropositive syphilis patients using a purified recombinant treponemal antigen $\mathrm{r} 17$, representing the concept of using this method for serological detection in medical models [132].

Most label-free optical biosensors necessitate specific light coupling to the sensing field, which is a significant disadvantage for point-of-care applications. As a result, when 
this technique is used in an integration system, optical detection can be significantly enhanced [117]. Integrated optics permit multiple passive and active optical components to be placed on the same substrate, allowing for the modular construction of small, lightweight sensing devices and the manufacturing of multiple sensors on a single chip.

A dual-functional plasmonic biosensor integrating the plasmonic photothermal (PPT) effect and localized surface plasmon resonance (LSPR) sensing transduction were applied by Qui et al. as an alternate and promising approach for clinical COVID-19 diagnosis [133]. The sensor was modified with 2D gold nano-islands (AuNIs) and functionalized with complementary DNA (cDNA) receptors by forming $\mathrm{Au}-\mathrm{S}$ bonds between the AuNIs and the thiolic groups of cDNA. No matter which approach is used in optical biosensors, biomarkers such as antigens or microRNAs can be accurately and rapidly detected. It is essential to reduce detection limitations (LODs) in order to identify a few analytes operating in cancer diagnosis [120]. Kaja et al. used an optical biosensor constructed regarding ovarian cancer biomarkers detection (fibronectin, apolipoprotein A1, and TIMP3). This progress is particularly significant in early diagnosis as $<20$ percent of ovarian cancer can be diagnosed in the early stages [134]. A photonic biosensor based on the silicon "lab-on-achip" for early-stage cancer has shown a sensitivity of at least 10 to 100 times greater than that of current commercial biosensors [135]. Shafiee et al. have demonstrated a mechanism free of etiquette optical sensing by nanostructured photonic crystals (PC). In resonant light with a broadband light source, the nanoplastic surface of the PC biosensor is a short wavelength band [65]. Surface-adsorbed bio targets cause a change in the resonant peak wavelength value (PWV), which can be detected with a resolution of $<10$ p.m., allowing both biomolecular layers and small numbers of viruses to detect that diminishing surface content of the transducer.

\section{Safety and Security}

Researchers must be mindful that infecting animals can add a new dimension to the risks, whether intentionally or unintentionally. All necessary permissible regulations and measures, including infectious agents, must be followed both before and after the experiment during an investigation. The safety and security measures for infectious agent experimentation must be approved by government policies or an in-house formed authority.

Take the necessary precautions and safety measures when working with biohazards, such as limiting access to the area to listed personnel only, decontaminating all surfaces and waste after each day of experimentation, not pipetting or spitting during an investigation, wearing personal protective equipment (including an eye mask and face shield), being familiar with the written instructions and documentation of the working area or experimentation, and adhering to the waste disposal procedures [136].

\section{Objective of the Present Review}

The current review discusses the latest advancements in the optical biosensors of human viral infectious diseases. This review focuses on the optical detection of COVID-19, MERS, SARS, Influenza, Hepatitis, HIV, HPV, Zika, Herpes simplex virus, Chikungunya, Dengue, and Rotavirus. All-important optical works are divided into sub-sections to better comprehend the sensor fabrication's primary idea/principle/working mechanism. The first section summarizes recent publications on optical biosensors for the detection of numerous life-threatening viruses. The following section exclusively discusses the various optical sensor systems, including calorimetrically, fluorescence, chemiluminescence, surface plasmon resonance, and photonic transduction methods. The key obstacles in transferring laboratory research into real-world device applications are described in detail. Optical sensors for viral detection are discussed in terms of prospects and commercialization. The background and overall progress presented in this paper can aid researchers in devising new novel ways to construct point-of-care optical diagnostic sensing systems for various 
pathogens, not just life-threatening viruses. Figure 1 conveys the overall summary of optical sensors towards the detection of the abovementioned selected infectious diseases.

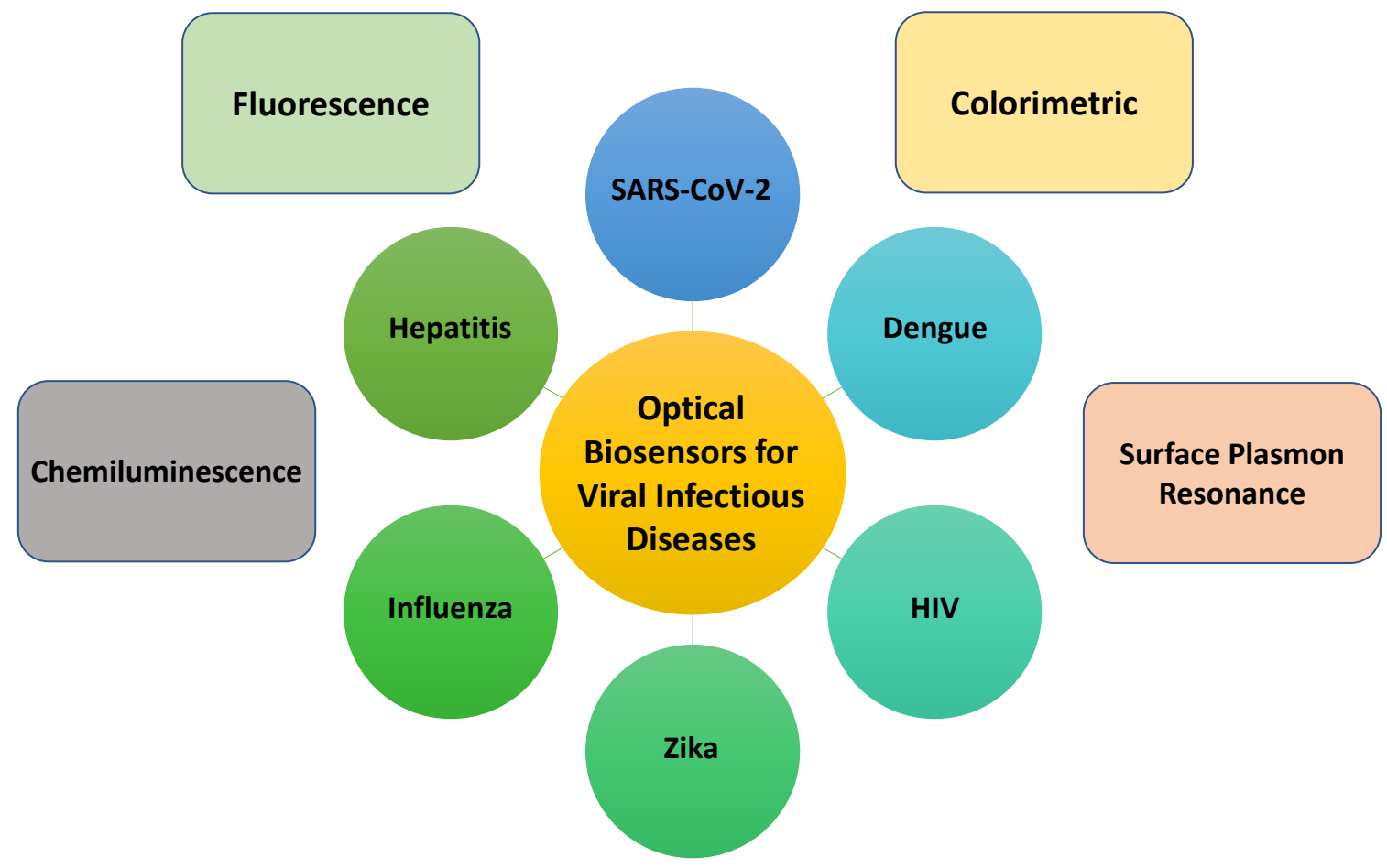

Figure 1. Schematic representation of the optical biosensors in viral infectious disease diagnostics.

\section{Optical Diagnostics}

Optical methods for virus detection have recently gained popularity due to their advantages of being fast, label-free, reusable, inexpensive, and portable for use at the point of care (POC) [34]. Noninvasive optical methods often preserve virus viability, making them useful for researching virus transmissibility, virulence, evolvability, and immunology [137]. Epitope variation, for example, may result in escape mutants being selected under immune strain, rendering either a possible detection tool or inactivation of vaccine $[138,139]$. The current state of art techniques in colorimetric, surface plasmonbased, fluorescence, and chemiluminescence have enabled faster, more sensitive detection with a low limit of detection [140-144].

\subsection{Colorimetric Sensors}

Sensors' technology utility in detecting a wide range of analytes quickly and efficiently has grown dramatically in recent years. The colorimetric sensors with a simple platform, quick response, fair sensitivity, and selectivity are among the most powerful and impressive devices for detecting microbes, biomolecules, and emerging contaminants $[145,146]$. In colorimetric biosensors, a complex ligand-target interaction results in a shift in color that can be seen with both the naked eye or be used as simple portable optical detectors for quantitative measurement $[147,148]$. It may be a solution or solid support. Rahman et al. [149] reported the development of a solution-phase bioassay protocol for the detection of dengue virus (DENV). This study demonstrated a label-free optical technique based on DNA/PNA hybridization and unmodified gold nanoparticles (AuNPs). In this approach, the unmodified AuNPs undergo an aggregation with neutral peptide nucleic acid (PNA) sequences, as they adsorb on the surface of AuNPs in the absence of targeted dengue virus. It showed a change in color from red to purple and resulted in a shift in wavelength from 520 to $650 \mathrm{~nm}$, which is due to the aggregation process of free PNA molecules and AuNPs without the addition of $\mathrm{NaCl}$ (5 M) [150]. With the addition of complementary 
dengue DNA, the G-quadruplex complex forms due to hybridization of the targeted DNA and PNA probes, and the AuNPs remained suspended and did not form aggregates. The color change was observed with a naked eye and with the UV-vis spectrum as well. A detection limit of $0.12 \mu \mathrm{M}$ for the PNA: DNA ratio (1:0.01) was calculated. Recently, a rapid diagnostic platform integrated with a low-cost reader and a multicolor 4-plex immunoassay was demonstrated to detect and distinguish between DENV IgM and IgG. With a detection time of $30 \mathrm{~min}$, the developed platform was useful in quantifying DENV and chikungunya virus (CHIKV) and IgM and IgG antibodies in human clinical samples (Figure 2) [141]. This multiplex assay possesses many advantages, such as a low sample volume and the ability to detect four analytes simultaneously over traditional rapid diagnostic tests used in resource-constrained environments. The Hook effect was neutralized in this study using a simple dilution approach [151].

A
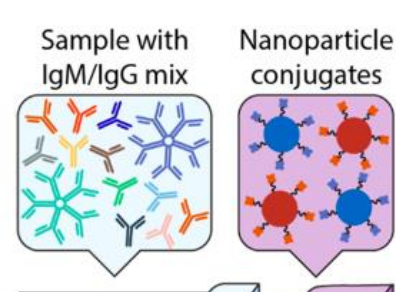

Test \& control lines interactions

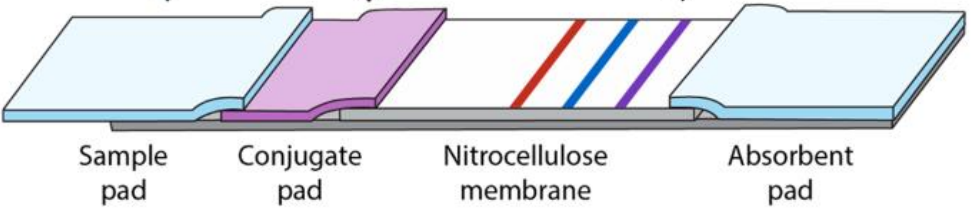

B
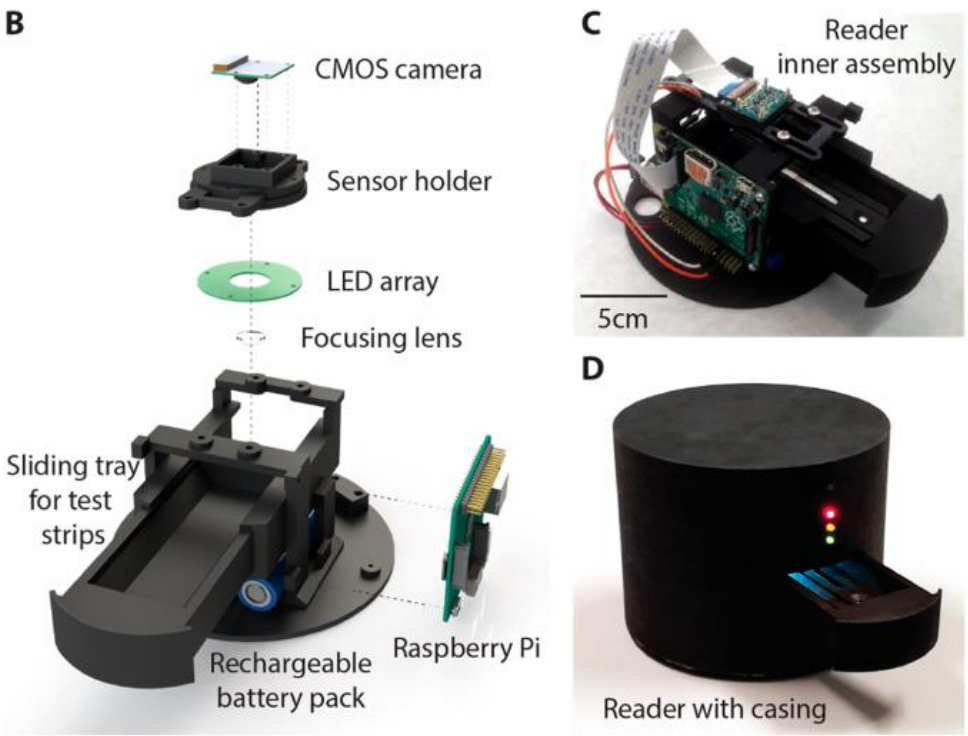

D
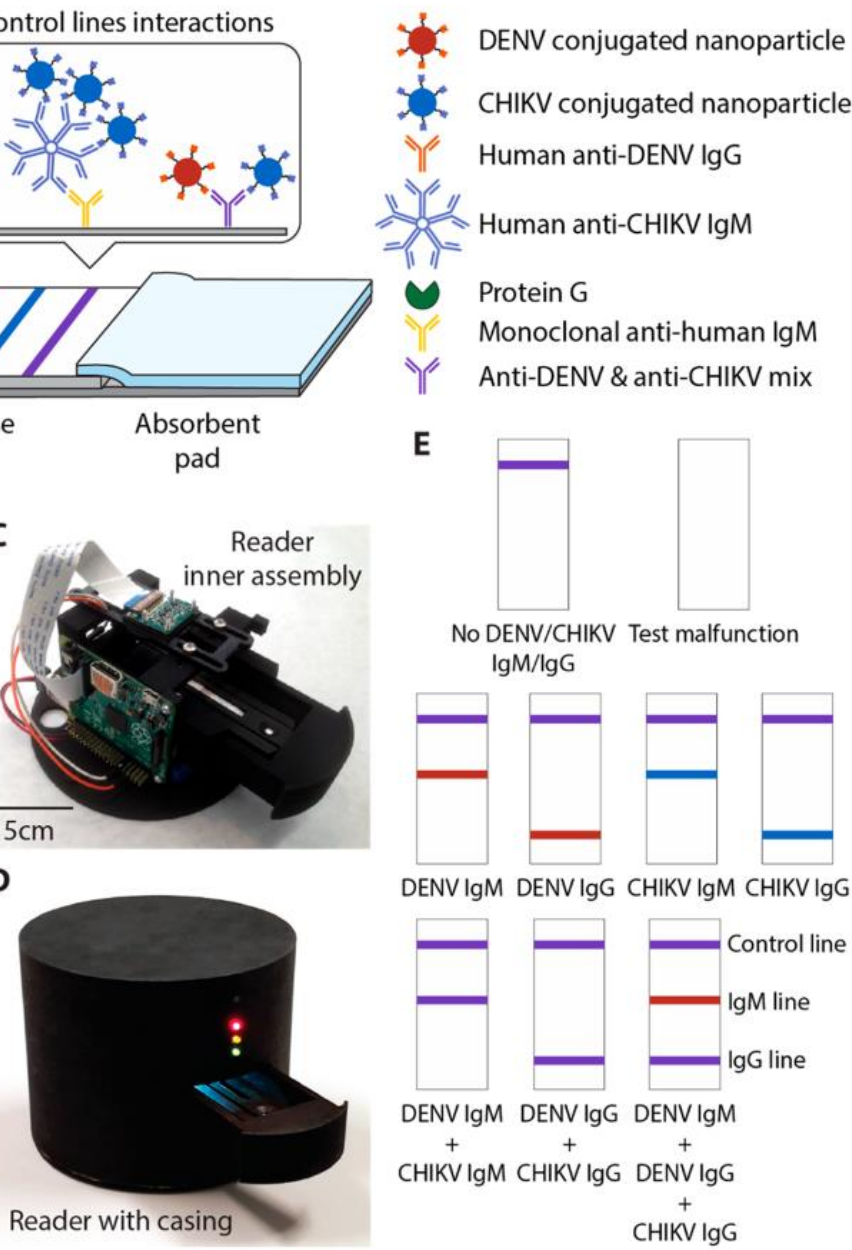

E

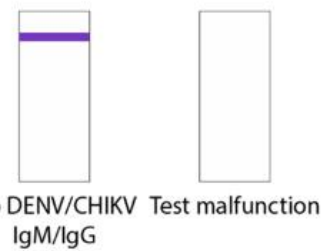
No DENV/CHIKV Test malfunction $\mathrm{M} / \mathrm{lgG}$

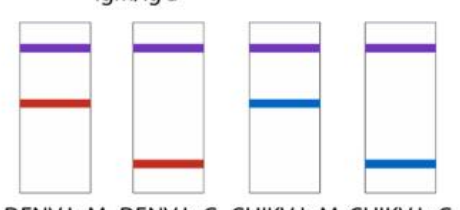

DENV IgM DENV IgG CHIKV IgM CHIKV IgG

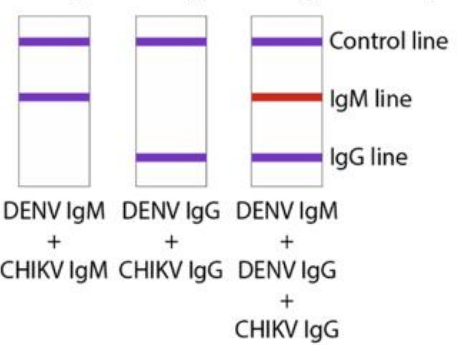

Figure 2. A 4-plex color encoded lateral flow test strip and an optical scanner make up this quick diagnostic platform. (A) Multiplex lateral flow test strip architecture. DENV and CHIKV antibodies can attach to red and blue nanoparticle conjugates, respectively. The first test line (red) captures nanoparticle conjugates labeled IgG, while the second test line (blue) captures labeled IgM, resulting in color development. When both DENV and CHIKV Ab of the same isotype are present in a sample, the test line generates an intermediate hue that is a mix of red and blue. The control line catches both unbound nanoparticle conjugates and unbound nanoparticle conjugates (purple). (B) An optical reader with an exploded view is designed to reduce color detection variations. (C) The optical reader's internal assembly. (D) is fully built and protected from the elements. To avoid ambient light, the open sliding tray is closed during imaging. The lights on the indicator show the progress of imaging. (E) Illustrations of test strip appearance for various diagnostic circumstances. DENV and CHIKV are both present in purple cases. Ab has the same isotype (adapted with permission from Wang et al. 2019 131, Copyright $\odot$ 2019, American Chemical Society) (adapted with permission from Wang et al. 2019 [141], Copyright (c) 2019, American Chemical Society). 
The binding affinity of hemagglutinin (HA) protein present on the surface of viral species with Sialic acid has been reported as one of the critical determinants for various viral species such as influenzas [152-154]. Conceptualizing the binding affinity of sialic acid to the viral surface, Lee et al. [155] proposed a colorimetric-sensing strategy utilizing sialic acid modified AuNPs to determine the influenza virus. A green method was used to synthesize and stabilize AuNPs with a size of $20.10 \pm 1.80 \mathrm{~nm}$. An increase in optical density and dilution of chemically inactivated influenza B virus exhibited an excellent linear relationship. The viral dilution of $0.156 \mathrm{vol} \%$ was readily detectable. However, the linearity can be further improved by using a higher concentration of sialic acid-stabilized AuNPs. In a recent study, a simple strategy for the in situ production of AuNPs films by mixing sodium formate and chloroauric acid $\left(\mathrm{HAuCl}_{4}\right)$, which can be implement on various surfaces, such as a 96-well plate, PDMS, etc. [156] was reported. The peroxidase-like catalytic activity of $\mathrm{Au}$ NP films and colloidal (+)Au NPs against TMB-H2O2 mixtures was used to establish a responsive and quantitative method for colorimetric detection of influenza virus A (H1N1) (Figure 3A). An ELISA was used to confirm the conjugation of the anti-NA antibody with (+)Au NPs (Figure 3B). A linear range from $10 \mathrm{pg} \mathrm{mL}^{-1}$ to $10 \mu \mathrm{g} \mathrm{mL}^{-1}$ (Figure 3C) with LOD of $50.50 \mathrm{pg} \mathrm{mL}^{-1}$ was established for New Caledonia/H1N1/1999 influenza virus, whereas, for clinically isolated influenza A virus (H3N2), a LOD of $24.3 \mathrm{PFU} \mathrm{mL} \mathrm{mL}^{-1}$ with a viral range from $10-50,000 \mathrm{PFU} \mathrm{mL}{ }^{-1}$ was demonstrated in a concentration-dependent manner. On a glass substrate, the developed platform exhibited a LOD of $4.5 \mathrm{pg} \mathrm{mL}$ with linearity up to $10.0 \mathrm{pg} \mathrm{mL}^{-1}$ for avian influenza virus A (H5N1/ Vietnam 1203/04). A smartphone-integrated point-of-care platform utilizing AuNPs and ZnO nanorods reported the detection of avian virus [157]. This platform allows the detection of $2.7 \times 10^{4} \mathrm{EID}_{50} / \mathrm{mL}$ with the naked eye, whereas a smartphone imaging system improves the limit down to $8.0 \times 10^{3} \mathrm{EID}_{50} / \mathrm{mL}$, with a total time of $1.5 \mathrm{~h}$ required to complete the detection process. This developed platform with an integrated microfluidic system and smartphone-enabled plasmonic-based colorimetric detection possesses the inherent advantages of a portable, robust, fast, and user-friendly platform with higher sensitivity. Furthermore, this could help in the critical needs in low-resource areas for the monitoring of viral infection.

The detection of DNA molecules plays a vital role in the early diagnosis of genetic diseases. However, the conventional approaches rely on expensive equipment, which does not meet the demands of developing countries. A copper nanocluster-based colorimetric sensor for detection of the hepatitis B virus was published by Mao et al. [158]. The method showed excellent sensitivity and could detect viral load down to $12 \times 10^{9}$ molecules. The UV-vis absorbance at $420 \mathrm{~nm}$ (the maximum absorption of oxidized ABTS) and the logarithm (log) of target DNA concentration showed a good correlation, with increasing DNA concentration and observed UV absorption. The linearity of measurement was established between UV-vis absorbance at $420 \mathrm{~nm}$ (the maximal absorption of oxidized ABTS) and logarithm concentration of target DNA from 0 to $12.0 \times 10^{13}$ molecules with a correlation coefficient of $\mathrm{R}^{2}=0.99$ when concentration was increased from $12.0 \times 10^{9}$ to $12.0 \times 10^{13}$ target molecules. It was evident from the results that the addition of at least $12 \times 10^{9}$ target DNA molecules was required for catalytic activity, which confirms the detection limit of $12 \times 10^{9}$ molecules for analysis. For an early diagnostic of HBV infection, a colorimetric immunosensor was constructed utilizing conjugating magnetic separation and enzymatic catalysis [159]. This platform showed a relationship with an increase in HBsAg concentration in the $0.10-20 \mathrm{ng} \mathrm{mL}^{-1}$ ranges and OD450 $\mathrm{nm}$ with a detection limit of $0.012 \mathrm{ng} \mathrm{mL}^{-1}$. Furthermore, the performance of the immunosensor was also quantified in real human serum samples.

In another work, Mohammad et al. proposed a susceptible and selective colorimetric biosensing platform for detecting hepatitis $C$ virus [160]. With these considerations in mind, a straightforward strategy was devised to design a non-thiolated antisense oligonucleotide complementary to the $5^{\prime}$ UTR of the HCV viral genome. This $5^{\prime}$ UTR probe was explicitly designed to target HCV RNA in clinical samples. The interaction of citrate-capped Au NPs with a combination of the $5^{\prime}$ UTR probe and HCV viral RNA was studied in terms 
of Au NP stability (Figure 3D). The use of non-thiolated complementary oligonucleotides sequence avoids the chemical reaction for the conjugation of gold-thiol. This AuNP-based assay showed a vast range of $7.50 \times 10^{2}$ to $2.00 \times 10^{6} \mathrm{IU} \mathrm{mL}^{-1}$ viral load for HCV RNA detection in clinical samples with a limit of detection of $100 \mathrm{IU} \mathrm{mL} \mathrm{m}^{-1}\left(0.4 \mathrm{IU} \mu \mathrm{L}^{-1}\right)$ and turned-out time of $\sim 30 \mathrm{~min}$. Because of its high sensitivity and selectivity, the assay can be used for early and acute infection detection and disease control. Other viral diseases, such as SARS, Middle East respiratory syndrome (MERS), HIV, COVID-19, and others, can benefit from the strategy mentioned here.

A

(a)

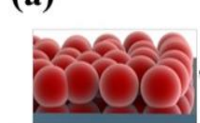

Au NPs film on

96 well plate (b)

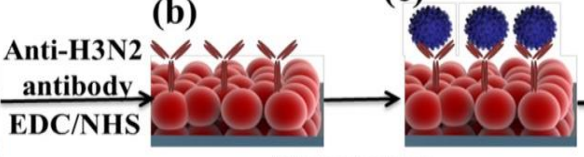

Target virus (d)

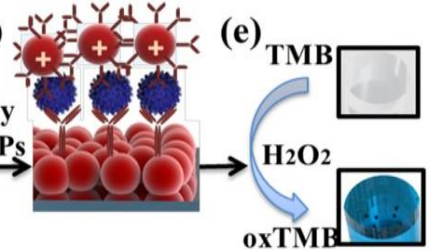

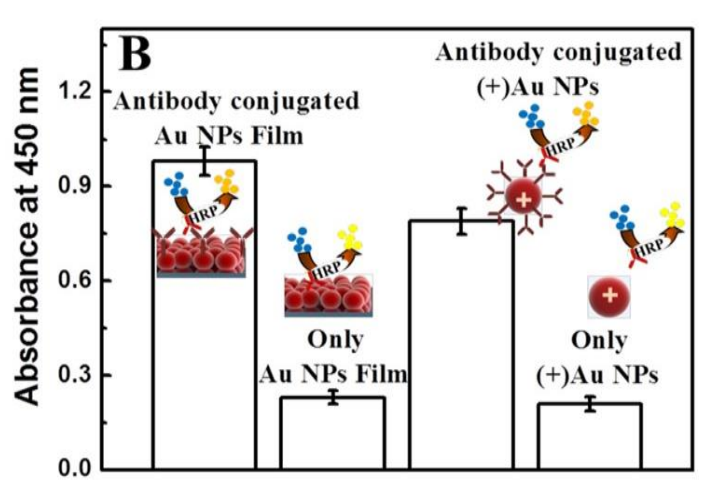
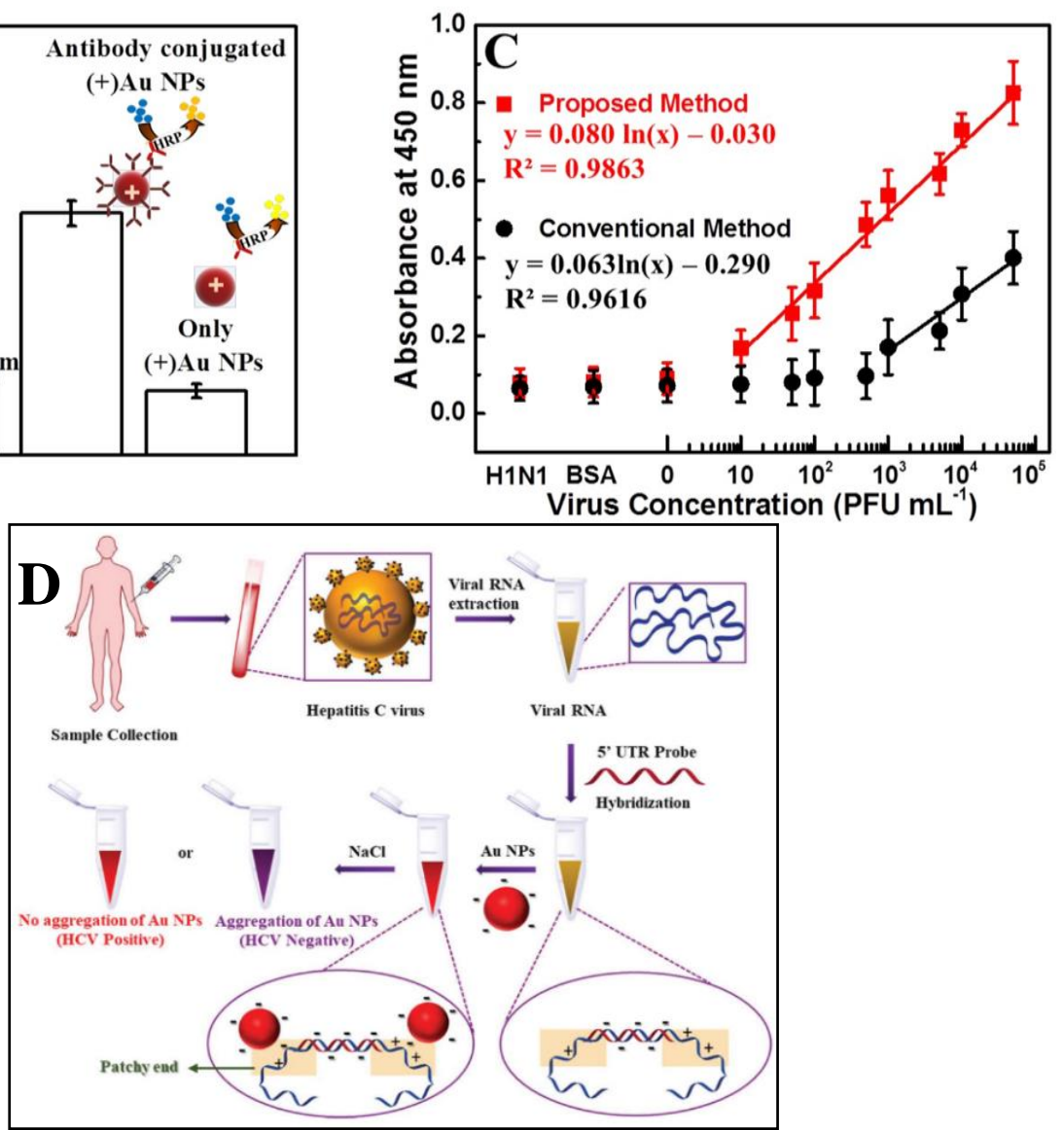

Figure 3. Design and detection of Influenza virus A (New Caledonia/20/1999) (H1N1) was discovered on film. (A) Virus detection schematic: (a) AuNP films on 96-well polystyrene plates; (b) anti-HA antibody immobilization on AuNPs using EDC/NHS chemistry. (c) The target virus was introduced after washing the NPs $(n=3)$ and incubated at room temperature for $30 \mathrm{~min}$. (d) The virus was bound by the anti-NA antibody-conjugated (+)AuNPs via an antibody-antigen reaction, and the unbound (+)AuNPs washed away. (e) TMB-H2O2 was added, and the oxidation of the peroxidase substrate TMB resulted in fast color shifts (oxTMB). (B) Anti-NA antibody binding to (+)AuNPs via electrostatic interactions as determined by ELISA. (C) The absorbance calibration curve for the influenza virus A concentration (New Caledonia/20/1999) (H1N1). H3N2-donated influenza virus A/Yokohama/110/2009 (H3N2) was used to test the system's specificity $(n=3)($ adapted with permission from Ahmed et al., Scientific Reports, 2017 [156]). (D) Representation of the AuNP-based assay strategy for HCV viral RNA sensing in clinical samples (adapted with permission from Mohammad et al., Analyst, 2021 [160]). 
Very recently, utilizing a collection of in-house built initiators targeting the region encoded the $\mathrm{N}$ protein, a loop-mediated isothermal amplification (LAMP) method was demonstrated to detect and amplify SARS-CoV-2 genetic sequences by González et al. [161]. Visual inspection was implemented to distinguish between positive and negative samples in this LAMP-based technique. They used color decomposition and analysis in the color CIELab space to quantify color differences between positive (yellow) and negative (red) samples. Furthermore, the sensitivity of this LAMP colorimetric system was compared to PCR protocols. This basic strategy could be sufficient for quickly deploying diagnostic efforts in the event of a COVID-19 pandemic. This strategy could detect and amplify SARSCoV-2 nucleic acids in the range of 625 to $2 \times 10^{5}$ DNA copies with $92.85 \%$ sensitivity and $81.25 \%$ specificity when 44 RNA extracted from patients were analyzed in a hospital.

Meanwhile, a colorimetric biosensor reported by Ventura et al. based on SARS-CoV2-induced gold nanoparticle (AuNP) interaction proves to be an excellent method for detecting viral particles in nasal and throat swabs [162]. The extinction spectrum is redshifted quickly when a colloidal solution of several viral-target gold nanoparticles (AuNPs) functionalized with antibodies targeting three surface proteins of SARS-CoV-2 (spike, envelope, and membrane) combined with a solution containing the viral particle. When the optical density of the mixed solution was calculated at $560 \mathrm{~nm}$ and compared to the threshold cycle $(\mathrm{Ct})$ of a real-time PCR (the gold standard for detecting the presence of viruses), it was observed that the colorimetric method detected very low viral load, with a similar detection limit to the former one. Another exciting aspect of the biosensor reported here is that it is sensitive to the virion rather than the content of the virion (RNA). The significance of this is twofold: first, after the optical response is calibrated, the biosensor becomes a potent instrument for quantifying viral load, a non-trivial issue in virology diagnostic procedures. Second, because the biosensor is exclusively sensitive to virions, it detects the presence of active viral particles; hence, our approach is suitable for determining the degree of infectivity of a sample.

From this study, the published results opened a new perspective in the sense of current and potential future pandemics and microbiology, as the biosensor demonstrates itself to be a powerful but easy tool for measuring viral particle concentration. Table 1 summarizes the colorimetric-based sensing platform reported for various kinds of viral infections.

Table 1. Reported colorimetric-based sensing platform for viral infection.

\begin{tabular}{|c|c|c|c|c|c|c|}
\hline S. No. & Antigen/Analyte & $\begin{array}{c}\text { Bio-Element/Detection } \\
\text { Strategy }\end{array}$ & Nanomaterial & $\begin{array}{c}\text { Detection/ } \\
\text { Linearity Range }\end{array}$ & LOD & Ref. \\
\hline 1. & DENV & PNA sequences & GNPs & 0.00 to $12.0 \mu \mathrm{M}$ & $0.12 \mu \mathrm{M}$ & [149] \\
\hline 2. & $\begin{array}{l}\text { DENV and CHIKV } \\
\text { IgG and IgM }\end{array}$ & Lateral-flow test strip & $\begin{array}{l}\text { Red and blue Latex } \\
\text { nanoparticles }\end{array}$ & - & - & [141] \\
\hline 3. & $\begin{array}{l}\text { New Caledo- } \\
\text { nia/H1N1/1999 } \\
\text { influenza virus }\end{array}$ & Peroxidase-like activity & AuNP films & $\begin{array}{l}10 \mathrm{pg} \mathrm{mL}^{-1}- \\
10 \mu \mathrm{g} \mathrm{mL}^{-1}\end{array}$ & $50.50 \mathrm{pg} \mathrm{mL}^{-1}$ & [156] \\
\hline 4. & $\begin{array}{c}\text { Influenza A virus } \\
\text { (H3N2) }\end{array}$ & Peroxidaselike activity & AuNP films & up to $10.0 \mathrm{pg} \mathrm{mL}^{-1}$ & $4.5 \mathrm{pg} \mathrm{mL}^{-1}$ & [156] \\
\hline 5. & $\begin{array}{l}\text { Influenza A virus } \\
\text { (H3N2) }\end{array}$ & $\begin{array}{l}\text { M149 antibody (Label-free } \\
\text { fluorescence-based } \\
\text { detection) }\end{array}$ & $\begin{array}{l}\text { Ab-Polydiacetylene (PDA) } \\
\text { Conjugate coated with } \\
\text { Polyvinylidene (PVDF) } \\
\text { Difluoride Membrane }\end{array}$ & & $30 \mu \mathrm{g} \mathrm{mL}^{-1}$ & [163] \\
\hline 6. & $\begin{array}{l}\text { Influenza H1N1 } \\
\text { virus }\end{array}$ & $\begin{array}{c}\text { Anti-influenza A HA-Ab } \\
\text { (Ab-E) and HRP-tagged } \\
\text { anti-influenza A HA-Ab } \\
(\mathrm{HRP}-\mathrm{Ab})\end{array}$ & Au immunostrip & 0 to $10,000 \mathrm{PFU} \mathrm{mL}-1$ & $\begin{array}{l}\text { 1.34 PFU mL } \mathrm{PL}^{-1} \text { (PBS) } \\
\text { 2.27 PFU mL }\end{array}$ & [164] \\
\hline 7. & $\begin{array}{l}\text { Avian influenza } \\
\text { virus }\end{array}$ & $\begin{array}{l}\text { Fluorescence } \\
\text { Reflection }\end{array}$ & AuNPs and $\mathrm{ZnO}$ nanorods & $\begin{array}{c}8.0 \times 10^{5} \text { to } 2.7 \times 10^{3} \\
\operatorname{EID}_{50} / \mathrm{mL}\end{array}$ & $\begin{array}{c}2.7 \times 10^{4} \mathrm{EID}_{50} / \mathrm{mL} \text { (naked eye) } \\
8.0 \times 10^{3} \mathrm{EID}_{50} / \mathrm{mL} \text { (smartphone } \\
\text { device) }\end{array}$ & [157] \\
\hline 8. & $\begin{array}{l}\text { Influenza A virus } \\
(\mathrm{H} 1 \mathrm{~N} 1)\end{array}$ & $\begin{array}{l}\text { Anti-hemagglutinin (HA) } \\
\qquad \mathrm{mAb}\end{array}$ & $\begin{array}{l}\text { Au Nanozymes and } \\
\text { Silica-shelled magnetic } \\
\text { nanobeads (MagNBs) }\end{array}$ & $\begin{array}{c}5.0 \times 10^{-15}-5.0 \times 10^{-6} \\
\mathrm{~g} \mathrm{~mL}^{-1}\end{array}$ & $\begin{array}{c}5.0 \times 10^{-12} \mathrm{~g} \mathrm{~mL}^{-1} \text { (human eyes) } \\
44.2 \times 10^{-15} \mathrm{~g} \mathrm{~mL}^{-1} \text { (microplate } \\
\text { reader) }\end{array}$ & [165] \\
\hline 9. & $\begin{array}{l}\text { NPs of influenza A } \\
\text { and B virus }\end{array}$ & $\begin{array}{c}\text { STA-RPA70A@biotin-HRP } \\
\text { and aptamer }\end{array}$ & - & $\begin{array}{l}0.1 \mathrm{pg} \mathrm{mL}^{-1} \text { to } \\
1 \mathrm{mg} \mathrm{mL}^{-1}\end{array}$ & $\begin{array}{l}0.30 \mathrm{pg} \mathrm{mL}^{-1} \\
0.16 \mathrm{pg} \mathrm{mL}^{-1}\end{array}$ & [166] \\
\hline
\end{tabular}


Table 1. Cont.

\begin{tabular}{|c|c|c|c|c|c|c|}
\hline S. No. & Antigen/Analyte & $\begin{array}{c}\text { Bio-Element/Detection } \\
\text { Strategy }\end{array}$ & Nanomaterial & $\begin{array}{c}\text { Detection/ } \\
\text { Linearity Range }\end{array}$ & LOD & Ref. \\
\hline 10. & Hepatitis B virus & DNA sequences & Cupper nanoclusters & $\begin{array}{c}12.0 \times 10^{9} \text { to } \\
12.0 \times 10^{13} \text { target } \\
\text { molecules }\end{array}$ & $12 \times 10^{9}$ molecules & [158] \\
\hline 11. & Hepatitis B virus & HBsAg & Magnetic nanoparticles & $0.10-20 \mathrm{ng} \mathrm{mL}^{-1}$ & $0.012 \mathrm{ng} \mathrm{mL}^{-1}$ & [159] \\
\hline 12. & Hepatitis $C$ virus & HCV oligonucleotides & AuNPs & $\begin{array}{c}7.50 \times 10^{2} \text { to } \\
2.00 \times 10^{6} \mathrm{IU} \mathrm{mL}^{-1}\end{array}$ & $\begin{array}{l}100 \mathrm{IU} \mathrm{mL}^{-1} \\
\left(0.4 \mathrm{IU} \mu \mathrm{L}^{-1}\right)\end{array}$ & [160] \\
\hline 13. & SARS CoV-2 & $\begin{array}{c}\text { Colorimetric } \\
\text { loop-mediated isothermal } \\
\text { amplification (LAMP) }\end{array}$ & - & $\begin{array}{c}625 \text { to } 2 \times 10^{5} \text { DNA } \\
\text { copies }\end{array}$ & 62.5 DNA copies & [161] \\
\hline
\end{tabular}

\subsection{Fluorescence/Chemiluminescence-Based Approaches}

A fluorophore substance is excited by a particular wavelength in a standard fluorescence measurement and then emits light at a different wavelength. The sensitive identification of the desired analytes present at a trace level in the sample necessitates the use of reporter molecules labeled with fluorescent dyes [167]. High detection sensitivity (single-molecule detection), quick response times, a localized fluorescence signal, multiplexed assays using multicolor dyes, and an uncomplicated labeling method that produces suitable functional groups on the target are all advantages of fluorescence detection [168].

To quantify hepatitis B viral DNA sequences, a FRET-based biosensor was designed using gold nanorods (AuNRs) and the fluorescein (FAM) molecule [169]. The AuNRs were generated using a seed-mediated surfactant method and then modified with cetyltrimethylammonium bromide (CTAB) to produce positively charged AuNRs. Figure 4a depicts the virus identification technique applied. When single-stranded FAM-labeled DNA was added to the AuNRs suspension, the DNA sequences adsorbed onto the positively charged AuNRs' surface. Fluorescence quenching occurs due to the development of the FAMssDNA-CTAB-AuNRs ternary complex and the FRET process from FAM to AuNRs. When complementary target DNA was added to the FAM-ssDNA-CTAB-AuNRs complex solution, the fluorescence intensity was reduced even more due to improved quenching effectiveness. Over a working range of $0.045-6.0 \mathrm{nmol} \mathrm{L}^{-1}$, the biosensor has a detection limit of $0.015 \mathrm{nmol} \mathrm{L}^{-1}(\mathrm{n}=3)$. Shen et al. [170] reported an ultrasensitive method to detect hepatitis B virus surface antigen ( $\mathrm{HBs} A g)$ in human serum. It employed a sandwich immunochromatographic assay (ICA) based on the signal amplification capability of highly luminescent quantum dot-beads (QBs) [170]. The sensor demonstrated a detection limit as low as $75.0 \mathrm{pg} \mathrm{mL}^{-1} \mathrm{HBsAg}$ in the working range of $75.0 \mathrm{pg} \mathrm{mL}^{-1}-75.0 \mathrm{ng} \mathrm{mL}^{-1}$. Yang et al. [171] proposed a new resonance light-scattering (RLS) sensor based on musselinspired hepatitis molecularly imprinted polymer to precisely detect trace quantities of Hepatitis A Virus (HAV). In this work, a polydopamine (PDA)-coated totivirus-imprinted polymer was introduced on the surface of $\mathrm{SiO}_{2}$ nanoparticles (virus-imprinted $\mathrm{SiO}_{2} @ P D A$ $\mathrm{NPs}$ ) as a recognition factor using an effective one-step syringe method (Figure $4 \mathrm{~b}$ ) with a low detection limit of $8.6 \mathrm{pmol} \mathrm{L}^{-1}$. The enhanced RLS intensity (IRLS) was proportional to the concentration of $\mathrm{HAV}$, in the range $0.04-6.0 \mathrm{nmol} \mathrm{L}^{-1}$.

For the sensitive detection of recombinant hemagglutinin ( $\mathrm{rHA}$ ) protein of the H5N1 influenza virus in human serum, a fluorescent aptasensor based on core-shell nanoparticles metal-enhanced fluorescence for H5N1 influenza virus detection (MEF) was designed [172]. Guanine-rich anti-rHA aptamers produced by SELEX were immobilized on the surface of $\mathrm{Ag} @ \mathrm{SiO}_{2}$ nanoparticles, which served as a metal-enhanced fluorescence (MEF) sensing tool. The fluorescent tag thiazole orange (TO) was used to report the G-quadruplex secondary structural induced by the aptamer-rHA binding case. The rHA protein of the H5N1 influenza virus was observed in aqueous buffer and human serum, with detection limits of 2.0 and $3.5 \mathrm{ng} \mathrm{mL}^{-1}$, respectively. Nonetheless, the issue of cost-consuming production and antigenic drift interference could be solved by using this aptamer-based biosensor, which is inexpensive and easy to use. More significantly, the entire detection process in a PE tube can be completed in $30 \mathrm{~min}$, making it a self-contained diagnostic kit for H5N1 influenza 
virus point-of-care (POC) diagnostic. Interestingly, a turn-on sensor constructed integrating tetraphenylethylene derivatives (a fluorescent probe) was proposed by Kato et al. [173]. The system used to manufacture these probes has the advantage of allowing ligands added to probe compounds through "click chemistry," a $\mathrm{Cu}(\mathrm{I})$-catalyzed azide-alkyne cycloaddition method that can speed up the manufacturing process. A concentration of $10^{5} \mathrm{pfu} / 100 \mu \mathrm{L}$ influenza virus was easily detected. Fukuyama et al. [174] reported the development of a multi-spectral fluorescent reporter influenza viruses (Color-flu) as powerful tools for in vivo studies. Color-flu viruses are powerful tools for analyzing fatal virus (H5N1 and H7N9) infections at the cellular level in vivo to understand influenza pathogenes.

Yang et al. published a three-dimensional Cu-based metal-organic framework-1 (MOF) that is water stable and supported by a tritopic quaternized carboxylate and 4,4'-dipyridyl sulfides as an ancillary ligand [175]. With detection limits of 196 and 73 pM, respectively, this device can be used as effective fluorescent sensors for human immunodeficiency virus one double-stranded DNA and Sudan virus RNA sequences. Very recently, a triple-mode (colorimetric/SERS/fluorescence) biosensor based on AuNPs was recently proposed for the rapid and selective detection of RNA in SARS-CoV-2 in $40 \mathrm{~min}$ [176]. Colorimetric, surface-enhanced Raman scattering (SERS), and fluorescence signals of sensors were observed simultaneously based on their specific aggregation property and affinity energy to distinguish AuNPs with an average size of $17 \mathrm{~nm}$. The sensor achieves a femtomole level detection limit of 160 FM in absorbance mode, 259 FM in fluorescence mode, and 395 FM in SERS mode in all triple modes. The triple-mode sensor's signals can detect the single-base mismatch, reduce SARS-CoV-2 false negative readings, and offer a new method for detecting COVID-19 and other fast, responsive, and selective diseases.

To detect anti-DENV IgM antibodies, an indirect chemiluminescence enzyme immunoassay (CLEIA) based on synthetic peptides selected from the envelope protein of DENV using computational calculations was reported by Zhu et al. [177]. For detection of avian influenza viruses (AIV) and other infectious and fatal viral avian-origin diseases, a signal-amplifiable nanoprobe-based chemiluminescent lateral flow immunoassay (CL-LFA) was developed by Zung et al. [178]. In the approach, antibodies (binding receptors) and enzymes (signal transducers) can be immobilized on sensitive paper-based sensor platforms using size-selective signal amplifiable nanoprobes (Figure 4C). The CL-detection LFA's limit for the nucleoprotein of the H3N2 virus using the signal-amplifiable nanoprobe was reported to be $5.0 \mathrm{pM}$. The CL-LFA exhibited higher sensitivity and specificity for detecting AIV in clinical specimens of swab samples taken from contaminated chicken hosts.

HTLV-II (Human T-lymphotropic Virus Type II) is a type-C retrovirus linked to several human diseases [179]. For the first time, the fabrication of a bio-bar code for dendritically amplified HTLV-II DNA sensing was reported by Wang et al. [180]. This method could detect HTLV-II DNA with a detection limit as low as $0.50 \mu \mathrm{M}$ and nine magnitudes higher dynamic range from $1.0 \mu \mathrm{M}$ to $1.0 \mathrm{nM}$. The three main reason for the above outcomes were: terminal deoxynucleotidyl transferase's (TdT's) efficient polymerization reaction, biobar-code amplification (BCA's) power, and G-rich DNAzyme-driven chemiluminescence's high sensitivity. For practical application, this strategy has the potential to distinguish between single-base mismatches and assess HTLV-II DNA in both human serum and human T-lymphocytic leukemia cells. A novel Pseudorabies virus (PRV) detection method based on MBs and chemiluminescence, with an intrinsic ability to detect as low as 100 amol PRV, was proposed by Yang et al. [181]. When compared to conventional PRV detection technologies, it offers a clear advantage. This method can be used in the swine industry for early detection of porcine pseudorabies due to its low cost, ultrasensitivity, and speed.

For quantitative determination of human serum HBsAg, a rapid capillary chemiluminescence immunoassay (CCIA) using a portable analyzer was established [182]. For application in clinical analysis, the sensitivity and specificity of the CCIA were validated in positive $\mathrm{HBsAg}(\mathrm{HBsAg}+)$ and negative HBsAg (HBsAg) human sera. Under the optimized experimental condition, the CCIA quantitatively detected human serum HBsAg levels at $0.4-15.0 \mathrm{ng} \mathrm{mL}{ }^{-1}$, resulting in dose-dependent increases in chemiluminescence $(C L)$ 
signals with a sensitivity of $0.3 \mathrm{ng} \mathrm{mL} \mathrm{mL}^{-1} \mathrm{HBsAg}$. Similarly, for HBsAg, a quick, sensitive chemiluminescence immunosensor with a broad linear range was developed [183]. Herein, the integration of AuNPs as carriers for luminol and secondary antibody resulted in signal amplification and a high specificity for HBsAg. Furthermore, $\mathrm{Au}^{3+}$ was used as a non-enzymatic catalyst to increase sensitivity. This platform was able to detect as low as $14 \mathrm{pg} \mathrm{mL}^{-1} \mathrm{HBsAg}$ in human serum.

The first line of defense against infectious disease is to locate infected patients as soon as possible. Addressing the problem of unavailable solutions for an early and accurate quantification of SARS-CoV-2, various strategic approaches based on chemiluminescence platforms have been recently reported [184-187]. Compared to false-negative results due to viral evolution in reverse transcriptase-PCR (Rt-PCR) results, the above platforms could measure SARS-CoV-2 as quickly and accurately as possible. Moreover, the applicability of these platforms to detect SARS-CoV-2 in the clinical sample has also been reported. For example, a dual lateral flow optical/chemiluminescence immunosensor for rapidly detecting salivary and serum IgA was identified in SARS-CoV-2 infected patients [188]. Table 2 summarizes the fluorescence and chemiluminescence platforms developed for the detection of viral antigens or antibodies.

Table 2. Fluorescence/chemiluminescence-based sensing platform for viral infection.

\begin{tabular}{|c|c|c|c|c|c|c|}
\hline S. No. & Principle & Analyte & Real Sample & Detection Range & LOD & Ref. \\
\hline 1. & \multirow{6}{*}{ Fluorescence } & $\begin{array}{c}\text { Detection of hepatitis B virus } \\
\text { DNA } \\
\text { (FRET-based) }\end{array}$ & $\begin{array}{l}\text { Human urine } \\
\text { sample }\end{array}$ & $0.045-6.0 \mathrm{nmol} \mathrm{L}^{-1}$ & $\begin{array}{l}0.015 \mathrm{nmol} \\
\mathrm{L}^{-1}\end{array}$ & [169] \\
\hline 2. & & $\begin{array}{c}\text { Hepatitis B virus surface antigen } \\
\text { (HBsAg) } \\
\text { sandwich immunochromatographic } \\
\text { assay (ICA) }\end{array}$ & $\begin{array}{l}\text { Human } \\
\text { Serum }\end{array}$ & $\begin{array}{l}75.0 \mathrm{pg} \mathrm{mL}^{-1}-4.80 \\
\mathrm{ng} \mathrm{mL} \\
4.80 \mathrm{pg} \mathrm{mL}^{-1}-75.0 \\
\quad \mathrm{ng} \mathrm{mL}^{-1}\end{array}$ & $75 \mathrm{pg} \mathrm{mL}^{-1}$ & [170] \\
\hline 3. & & Hepatitis A Virus (HAV) & $\begin{array}{l}\text { Human } \\
\text { Serum }\end{array}$ & $0.04-6.0 \mathrm{nmol} \mathrm{L}^{-1}$ & 8. $0 \mathrm{nmol} \mathrm{L}^{-1}$ & [171] \\
\hline 4. & & $\begin{array}{l}\text { Recombinant hemagglutinin (rHA) } \\
\text { protein of the H5N1 influenza virus }\end{array}$ & $\begin{array}{l}\text { Aqueous } \\
\text { Buffer } \\
\text { Human } \\
\text { serum }\end{array}$ & $0.0-200.0 \mathrm{ng} \mathrm{mL}^{-1}$ & $\begin{array}{l}2.0 \mathrm{ng} \mathrm{mL}^{-1} \\
3.5 \mathrm{ng} \mathrm{mL}^{-1}\end{array}$ & {$[172]$} \\
\hline 5. & & $\begin{array}{l}\text { Human immunodeficiency virus } 1 \\
\text { double-stranded DNA sequence } \\
\text { Sudan virus RNA sequence }\end{array}$ & - & - & $\begin{array}{l}196 \mathrm{pM} \\
73 \mathrm{pM}\end{array}$ & [175] \\
\hline 6. & & $\begin{array}{l}\text { SARS-CoV-2 } \\
\text { virus specific genes }\end{array}$ & TE buffer & $0.01-1.0 \mathrm{pM}$ & $160 \mathrm{fm}$ & [176] \\
\hline 7. & \multirow{8}{*}{ Chemiluminescence } & anti-DENV IgM antibodies & Serum & - & - & [177] \\
\hline 8. & & Avian influenza viruses (AIV) & $\begin{array}{l}\text { Embryonated } \\
\text { chicken eggs }\end{array}$ & $1.0 \mathrm{pM}-1.0 \mathrm{nM}$ & $5.0 \mathrm{pM}$ & [178] \\
\hline 9. & & $\begin{array}{c}\text { Human } \\
\text { T-lymphotropic viruses }\end{array}$ & $\begin{array}{l}\text { Human } \\
\text { Serum }\end{array}$ & $1.0 \mathrm{aM}-1.0 \mathrm{nM}$ & $0.50 \mathrm{aM}$ & {$[180]$} \\
\hline 10. & & Pseudorabies Virus & Swine & $\begin{array}{c}1.0 \times 10^{1} \\
-1.0 \times 10^{8} \mathrm{amol}\end{array}$ & $100 \mathrm{amol}$ & {$[181]$} \\
\hline 11. & & $\begin{array}{c}\text { Hepatitis } \\
\text { B surface antigen (HBsAg) }\end{array}$ & Serum & $0.40-15.0 \mathrm{ng} \mathrm{mL}^{-1}$ & $0.30 \mathrm{ng} \mathrm{mL}^{-1}$ & [182] \\
\hline 12. & & HBsAg & Serum & $0.12-30 \mathrm{ng} \mathrm{mL}^{-1}$ & $14.0 \mathrm{pg} \mathrm{mL}^{-1}$ & {$[183]$} \\
\hline 13. & & H1N1 influenza virus & - & $\begin{array}{c}1.0 \times 10^{-12}-1.0 \times 10^{-6} \\
\mathrm{~g} \mathrm{~mL}^{-1}\end{array}$ & $\begin{array}{c}1.0 \times 10^{-13} \\
\mathrm{~g} \mathrm{~mL}^{-1}\end{array}$ & [189] \\
\hline 14. & & $\begin{array}{c}\text { Human Immunodeficiency Virus } \\
\text { type } 1 \text { (HIV-1) }\end{array}$ & $\begin{array}{l}\text { Human } \\
\text { Serum }\end{array}$ & $0.020-1.0 \mathrm{pM}$ & $5.0 \mathrm{fM}$ & [190] \\
\hline
\end{tabular}




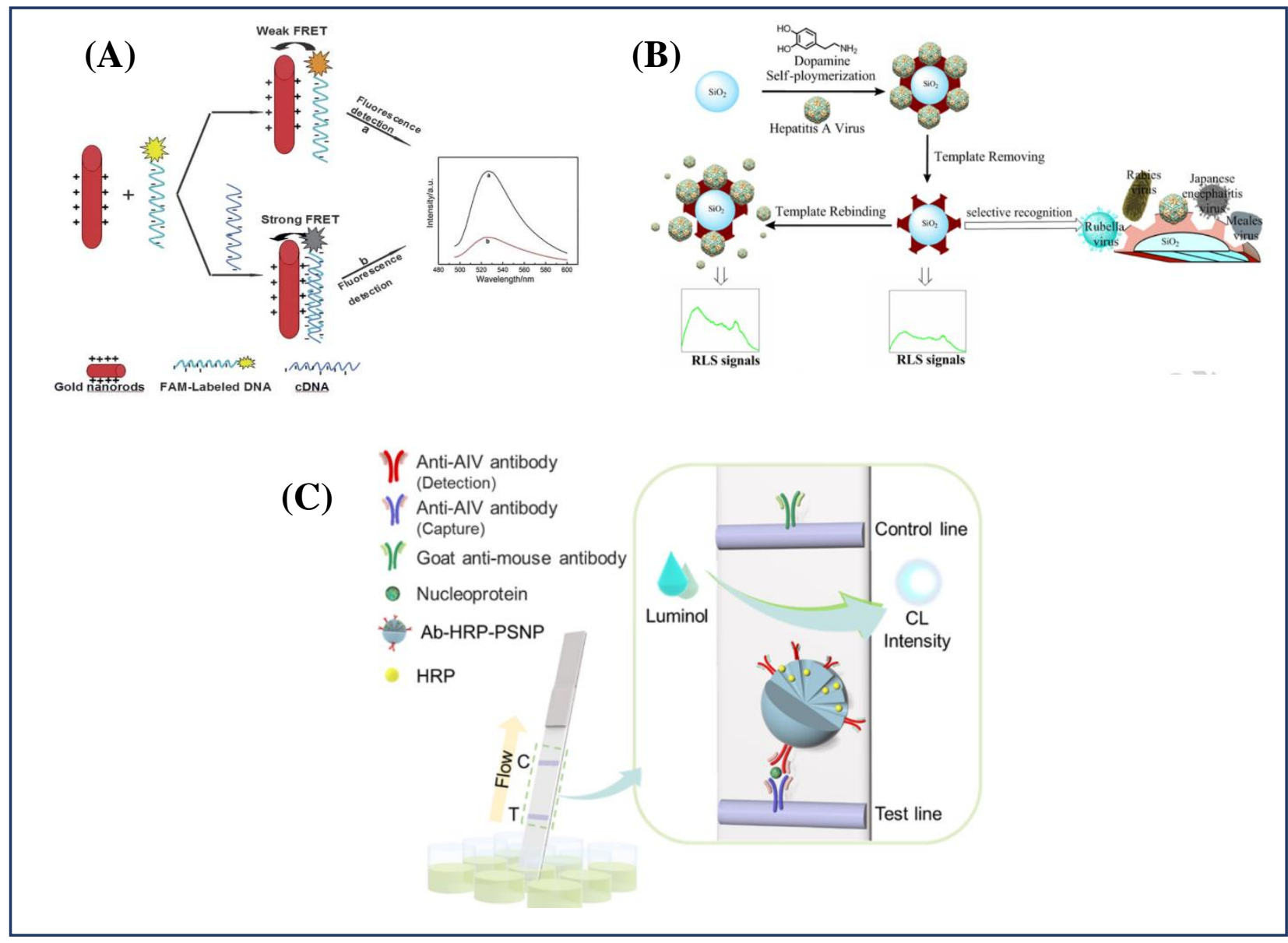

Figure 4. (A) Schematic representation of the strategy for DNA hybridization detection (adapted with permission from Lu et al., Analyst, 2013 [169]); (B) Principle of preparation of the virus-MIPs and detection of virus (Hepatitis A) (adapted with permission from Yang et al., Biosensors, and Bioelectronics, 2017 [171]); (C) Schematic illustration of porous silica nanoparticle-based chemiluminescent lateral flow immunoassay (CL-LFA) platform for the detection of avian influenza virus (AIV) nucleoproteins (adapted with permission from Jung et al., Analytical Chemistry, 2021 [178]).

\subsection{Surface Plasmon Based Approaches}

Longitudinal electron concentration waves produced on the metal-dielectric interface by p-polarized light incidence are known as surface plasmons (SP). Matching a momentum between an incident photon and the SP causes the phenomenon of resonance. SPR biosensors that detect and measure molecular interactions are based on surface plasmon resonance (SPR), which is sensitive to surface states [131]. However, in real-time, there are no labels. The existing literature witnessed the development of various SPR-based biosensors for viral diagnostics [140].

An SPR-based sensing platform was constructed utilizing the random nanoislands to excite and localize SPs and control associated evanescent nearfields for enhanced detection sensitivity for viral particles detection [191]. The theoretical and functional data presented in this paper, on the other hand, do not reflect the best possible solution or any change in LOD or sensitivity. Furthermore, because of the limitations in computational models of nanoislands, theoretical analyses tend to be negative. Using immobilized recombinant Ebola nucleoprotein (EBOV-rNP) on a 4-mercaptobenzoic acid (4-MBA/ $\mathrm{Au}$ )modified SPR gold chip (EBOV-rNP/4-MBA/Au), an SPR technique was developed for screening different monoclonal antibodies ( $\mathrm{mAb} 1, \mathrm{mAb} 2$, and $\mathrm{mAb3}$ ) of EBOV in realtime [192]. The 4-MBA/Au SPR chip formation was characterized by SPR, electrochemical impedance spectroscopy (EIS), and attenuated total reflectance Fourier-transform infrared spectroscopy (FTIR-ATR). Among the three antibodies used, the best antibody was cho- 
sen based on the affinity constant and used to detect EBOV-rNP in a phosphate-buffered saline (PBS) medium. The interaction of Ebola mAb1, mAb2, and mAb3 with immobilized EBOV-rNP was found to have KD values of 809 nM, 350 pM, and 52 pM, respectively, indicating mAb3's high affinity. With mAb3, the SPR limit of detection for EBOV-rNP was $0.5 \mathrm{pg} \mathrm{mL}^{-1}$.

Using a selected aptamer as the recognition factor, Bai et al. proposed the development of an SPR-based biosensor for the detection of avian influenza virus (AIV) H5N1. The sensing system was created by streptavidin-biotin-binding to immobilize a biotinylated aptamer over a streptavidin-coated gold surface [193] (Figure 5A). The RI value was linearly connected $\left(\mathrm{R}^{2}=0.99\right)$ to the concentration of AIV in the range of 0.128 to 1.28 HAU (HA unit) after optimizing the streptavidin and aptamer parameters. This aptasensor found AIV H5N1 in poultry swab samples with concentrations ranging from 0.128 to 12.8 HAU in $1.5 \mathrm{~h}$. An inhibition assay using HA protein deposited over the sensor chip to identify whole viruses was used to quantify AIV H1N1 and H3N2 [194]. This SPRbased optical fiber sensor's detection surface was prepared using a plasma modification method for chemically binding a self-assembled monolayer of isopropanol to the gold surface of the optical fiber. Preliminary research revealed susceptible virus detection in the range of $0.5-10 \mu \mathrm{g} \mathrm{mL}^{-1}$ and increased precision with a response time of $10 \mathrm{~min}$. Quantification of HA via single-radial immunodiffusion (SRID) quantification is the most popular approach for ensuring product potency in seasonal influenza vaccines. Based on the above phenomenon, a fiber optic SPR-based sensing strategy to detect AIV subtype H6N1 has been reported [194]. The method uses an inhibition assay format with HA proteins for H1N1, H3N2, and B immobilized on a sensor chip to quantify the virus. In comparison to SRID, preliminary results showed that the assay had higher sensitivity (detection range $0.50-10 \mu \mathrm{g} \mathrm{mL}^{-1}$ ), precision, analysis, and hands-on time. The detection limit of $<0.50 \mu \mathrm{g} \mathrm{mL}^{-1}$ was quantified. Lepage et al. [195] demonstrated an innovative quantum-well SPR-based configuration for real-time AIV A diagnostics. As compared to a traditional prism-based SPR design, it revealed a time resolution of $2.2 \mathrm{~s}$ for data acquisition, yielding a resolution of $1.5 \times 10^{-6}-2.7 \times 10^{-5}$ RIU. H5Nx whole virus detection using a highly sensitive and specific sandwich-type SPR-based biosensor reported by Nguyen et al. [196]. Herein, in a Multi-GO-SELEX process, aptamers sequences were successfully screened and characterized for whole avian influenza (AI) viruses, $\mathrm{H} 5 \mathrm{Nx}$, for the first time. The aptasensor was efficient in the range of $8 \times 10(4)$ to $1 \times 10(4) \mathrm{EID} 50 / \mathrm{mL}$ with a detection limit of 200 EID50/mL for H5N1 virus.

A study on an SPR-based approach for dengue diagnosis used DENV E-protein as a target and IgM antibodies as a ligand [197]. Figure 5B shows a schematic representation of the proposed Au/DSU/NH2rGO-PAMAM/IgM sensor with DENV-2 E-proteins added. The sensor operating range was determined to be $0.08 \mathrm{pM}$ to $0.5 \mathrm{pM}$, with a detection limit of $0.08 \mathrm{pM}$ within $8 \mathrm{~min}$ with sensitivity and binding affinity values of $0.2576^{\circ} \mathrm{pM}^{-1}$ and $6.6844 \mathrm{TM}^{-1}$, respectively. The immobilization efficiencies of variously changed surfaces were compared using model proteins with different surface charges, such as streptavidin, due to the high protein-immobilization efficiency of the plasma-treated parylene-N film [198]. Herein, an SPR biosensor based on the plasma-treated parylene-N film was developed to detect human hepatitis virus surface antigen (HBsAg), and the plasma-treated parylene-N film was estimated for improved sensitivity. Detection of HBsAg was possible in the concentration range of $10 \mathrm{pg} \mathrm{mL}^{-1}$ to $1 \mu \mathrm{g} \mathrm{mL}^{-1}$, with a detection limit of less than $10.0 \mathrm{pg} \mathrm{mL}^{-1}$ estimated.

In one study, a protein produced by the fusion of gold binding polypeptides (GBPs) was used to develop an SPR-based sensor for the quick and easy detection of coronavirus [18]. These were immobilized on top of the gold layer and used as a ligand for the surface antigen of SARS-CoV. The proposed sensor worked better when the fusion protein concentration was calibrated to upto $10 \mu \mathrm{g} \mathrm{mL}{ }^{-1}$. The sensor's detection limit and response time were stated to be $200 \mathrm{ng} \mathrm{mL}^{-1}$ within $10 \mathrm{~min}$. SPR was also used to investigate the kinetics of SARS-CoV-2, chimeric SARS-CoV-2, and SARS-CoV receptor 
binding domains (RBDs) with ACE-2 receptors [199]. Due to the existence of an additional $\mathrm{N}-\mathrm{O}$ bridge between chimeric SARS-CoV-2 RBD and ACE-2, the study discovered that the chimeric standardized SARS-CoV-2 RBD had a higher binding affinity for ACE-2 receptors. A one-step method was used to prepare DNA-silver nanoparticle (AgNP) conjugates (Figure 5C), which were then used to quantitatively detect HIV DNA using a sandwich strategy based on their powerful SPR scattering signal [200]. This platform could detect HIV DNA in the range of $0.30-2.0 \mathrm{nmol} \mathrm{L}^{-1}$. Table 3 presents various SPR-based sensors for virus detection, along with their detection ranges and limits of detection.
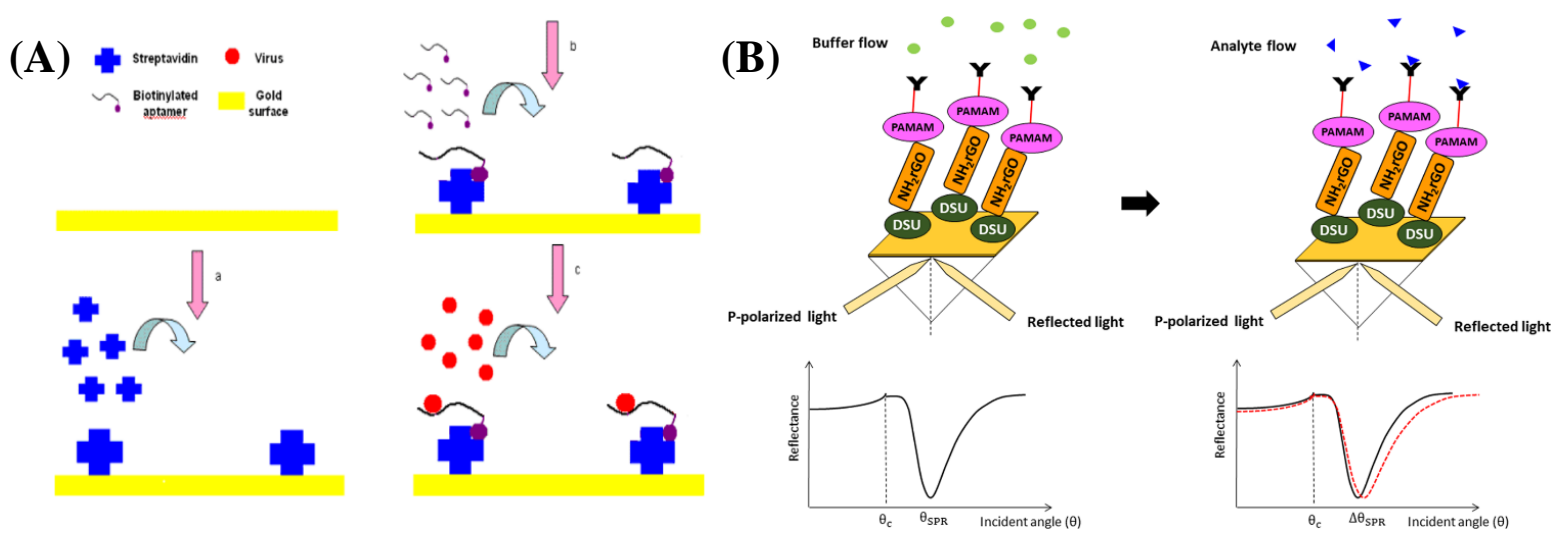

(C)

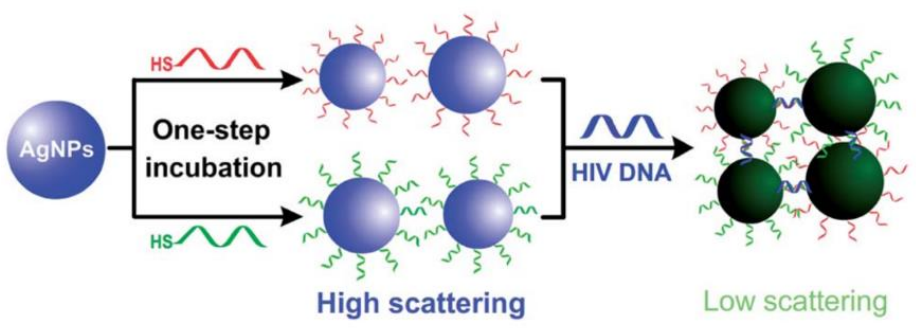

Figure 5. (A) Principle of SPR biosensor for detection of AIV H5N1: (a) Streptavidin immobilization; (b) Biotinylated apTable; (c) Virus detection. 2012. @MDPI [193]); (B) Schematic illustration of the SPR signal before and after the analyte flow (Adapted from Omar et al., Scientific Reports, 2020 [197]); (C) Schematic demonstration for the preparation of DNA-AgNP conjugates through one-step conjugation chemistry and a sandwich strategy for HIV DNA detection. Red (DNA1) and green (DNA2) strands represent 2 probe DNAs that can hybridize with HIV DNA (Adapted with permission from Liu et al., Analyst, 2012 [200]).

Table 3. Reported SPR-based sensing platform for viral infection.

\begin{tabular}{|c|c|c|c|c|c|c|}
\hline S. No. & Antigen/Analyte & Bio-Element & Real Sample & Detection Range & LOD & Ref. \\
\hline 1. & $\begin{array}{c}\text { Avian Influenza Virus } \\
\text { H5N1 }\end{array}$ & Aptamer & Poultry swab & 0.128 to $1.28 \mathrm{HAU}$ & $0.128 \mathrm{HAU}$ & [193] \\
\hline 2. & $\begin{array}{c}\text { Avian influenza virus } \\
\text { subtype H6 }\end{array}$ & Monoclonal antibodies & $\begin{array}{l}\text { Tracheal samples } \\
\text { from chicken }\end{array}$ & $0.50-10 \mu \mathrm{g} \mathrm{mL}-1$ & $\begin{array}{c}5.14 \times 10^{5} \\
\operatorname{EID}_{50} / 0.1 \mathrm{~mL}\end{array}$ & [158] \\
\hline 3. & Influenza Virus & Antibodies/Protein & Serum & $0.50-10 \mu \mathrm{g} \mathrm{mL}^{-1}$ & $<0.50 \mu \mathrm{g} \mathrm{mL}^{-1}$ & [194] \\
\hline 4. & DENV protein & $\operatorname{IgM~Ab}$ & - & $0.08 \mathrm{pM}$ to $0.5 \mathrm{pM}$ & $0.08 \mathrm{pM}$ & [197] \\
\hline 5. & $\begin{array}{l}\text { Human hepatitis } \\
\text { virus surface antigen } \\
\text { (HBsAg) }\end{array}$ & Antibodies & - & $10 \mathrm{pg} \mathrm{mL}^{-1}-1 \mu \mathrm{g} \mathrm{mL}^{-1}$ & $10 \mathrm{pg} \mathrm{mL}^{-1}$ & [198] \\
\hline 6. & SARS-CoV & $\begin{array}{c}\text { Goldbinding } \\
\text { polypeptides (GBPs) }\end{array}$ & - & $0-10 \mu \mathrm{g} \mathrm{mL}^{-1}$ & $200 \mathrm{ng} \mathrm{mL}^{-1}$ & [18] \\
\hline 7. & Hepatitis B & $\begin{array}{c}\text { Monoclonal hepatitis B } \\
\text { (HBsAb) }\end{array}$ & $\begin{array}{l}\text { buffer, blood serum } \\
\text { and plasma }\end{array}$ & $0.01-1.0 \mathrm{IU} / \mathrm{mL}$ & $0.01 \mathrm{IU} / \mathrm{mL}$ & [201] \\
\hline 8. & HIV DNA & DNA & - & $0.30-2.0 \mathrm{nmol} \mathrm{L}^{-1}$ & $\sim 195 \mathrm{pmol} \mathrm{L}^{-1}$ & [200] \\
\hline
\end{tabular}




\subsection{Photonic Sensors}

The photonic crystals (PCs) are dielectric and nanostructured materials with optical sensing properties that have a wide variety of applications, such as PC-based biosensors, and have been employed to detect various biological molecules and analyte [202-205]. This is due to the improved sensing performance in terms of sensitivity and selectivity [204]. A label-free biosensor based on inverse opal PC structures for detecting intact Rotavirus was presented in an experimental sample [24]. The peak wavelength value (PWV) shift was used to analyze virus detection success concerning virus concentration. The PWV shift suggested the quantitative concentration of the same target virus agents. The proposed system's sensitivity was comparable to or better than a commercial ELISA package with a detection limit of $2.54 \mu \mathrm{g} \mathrm{mL}^{-1}$. A photonic biosensor developed with a compact twodimensional hexagonal PhC over the gold film detected $1.0 \times 10^{-3} \mu \mathrm{g} \mathrm{mL} \mathrm{m}^{-1}$ Epstein-Barr nuclear antigen-1 (EBNA-1) protein [22]. The author also performed the simulation studies, where the simulation results confirm the SPP's tighter spatial confinement and higher local field strength, which aids in detecting slight changes in the refractive index on the sensor surface. A field diagnostic system based on a combination of advanced biosensing and photonics technologies for the detection of swine virus was proposed by Griol et al. [206]. The plan was focused on the use of CMOS (Complementary Metal Oxide Semiconductor) compatible microring resonators fabricated in silicon nitride. A detection limit of $7.13 \times 10^{-6}$ RIU was calculated using this planer resonator system.

To capture and quantify intact viruses (HIV-1) from biologically relevant samples, a label-free optical sensing mechanism using nanostructured photonic crystals (PC) was developed by Shafiee et al. [65]. During illumination with a broadband light source, the nanostructured surface of the PC biosensor resonantly reflects a narrow wavelength band. Surface-adsorbed bio targets cause a change in the resonant PWV that can be detected with a wavelength resolution of $10 \mathrm{pm}$, allowing identification of biomolecular layers and a small number of viruses that populate the transducer surface sparsely, as depicted in Figure 6.

The output of a sensitive tapered fiber sensor for label-free detection of DENV II E proteins was developed and investigated. With a sensitivity of $5.02 \mathrm{~nm} / \mathrm{nM}$ and a detection limit of $1.0 \mathrm{pM}$, the sensor design successfully detected DENV E proteins [207]. Herein, the researchers have developed and investigated the performance of a sensitive tapered fiber sensor for label-free detection of DENV II E proteins. The designed sensor had enough potential and yielded a sensitivity value of $5.02 \mathrm{~nm} / \mathrm{nM}$ and a detection limit of $1 \mathrm{pM}$. Compared to current Dengue diagnostic research efforts, the sensor has achieved higher specificity and sensitivity within a 15-minute detection period. The sensor's ability to work in experimental conditions was validated by spike and recovery analysis, which showed performance in the range of 83 percent to 89 percent.

In another study by Endo and co-workers, and antibody-immobilized flexible nanoimprint lithography (NIL)-based two-dimensional (2D)-PC biosensor was used to demonstrate the reflectometric detection of influenza virus in human saliva [23]. This resulted in a shift in reflection strength corresponding to influenza virus concentrations, using an antibody-immobilized 2D-PC biosensor. Furthermore, this method detected influenza virions in human saliva (detection limit: $1.0 \mathrm{ng} \mathrm{mL}^{-1}$ ) with a broader working range from $1 \mathrm{pg} \mathrm{mL} \mathrm{mL}^{-1}-100 \mathrm{ng} \mathrm{mL}^{-1}$ in a human saliva sample. This method offers a variety of analytical systems to create new rapid diagnostic procedures for severe viral diseases. Table 4 presents various photonics-based sensors for virus detection with their limit of detection and working range. 
(a)

\section{Surface Modification}

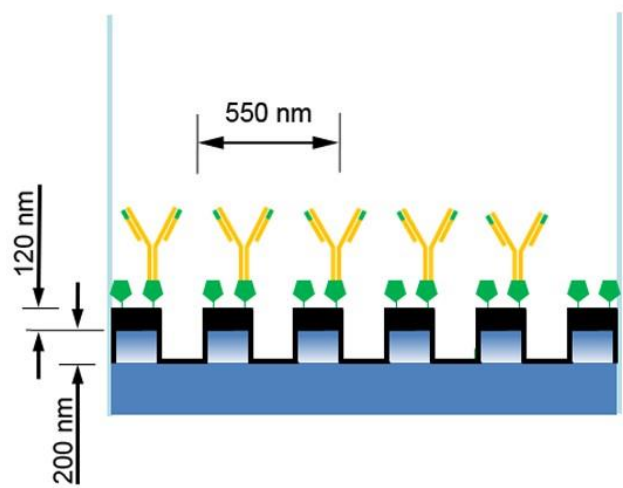

(b)

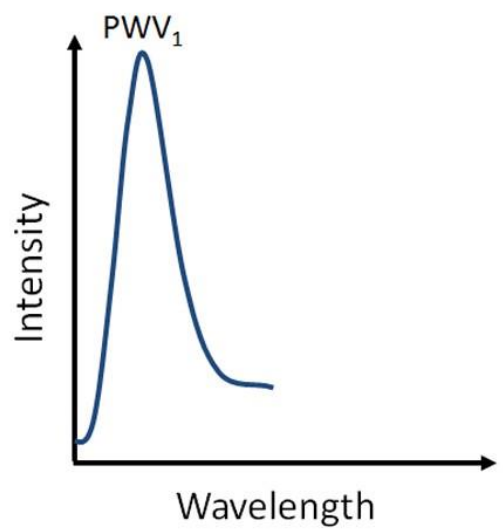

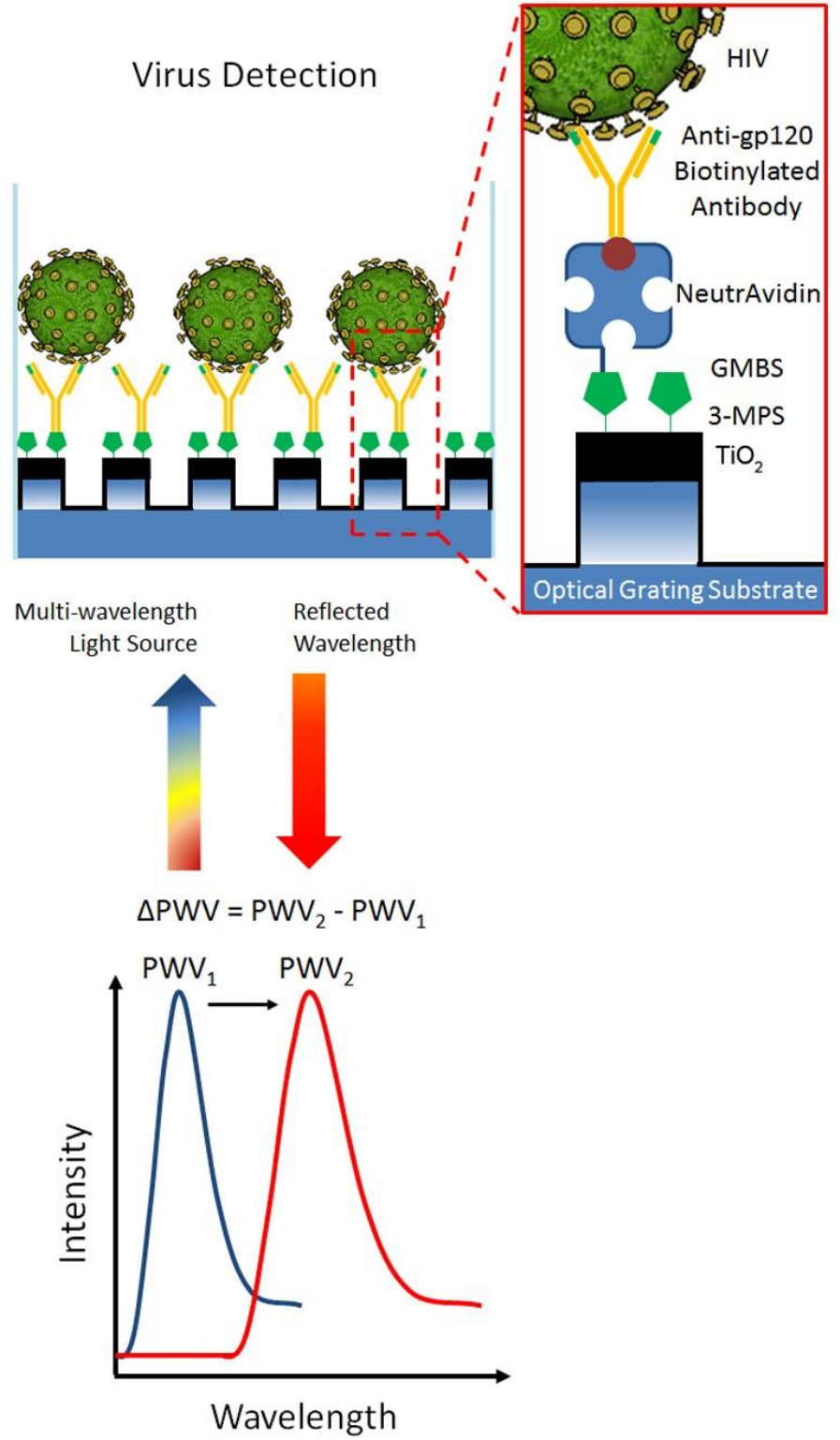

Figure 6. Design and construction of photonic crystal (PC)-based intact virus detection platform. (a) The bottom surface of PC biosensor microplate wells comprises a nanostructured subwavelength grating coated with $\mathrm{TiO}_{2}$. (b) Binding events within the close vicinity of the sensing area change the bulk index of refraction; thus, the reflected light's peak wavelength value $(\mathrm{PWV})$ is altered. The shift in the peak wavelength $(\triangle \mathrm{PWV})$ is directly proportional to the binding of molecules and bioagents (e.g., cells and viruses) onto the biosensing surface (adapted with permission from Shafiee et al., Nature Reports 2014 [65]).

Very recently, a single-step 15-minute assay capable of detecting as low as $100 \mathrm{pg} \mathrm{mL}^{-1}$ human COVID-19 IgG was designed based on photonic resonator absorption microscopy (PRAM) by Zhao et al. [208]. The LOD and LOQ were determined to be $26.7 \pm 7.7$ and $32.0 \pm 8.9 \mathrm{pg} \mathrm{mL}^{-1}$, respectively. In this work, for the first time, the Activate Capture + Digital Counting (AC + DC)-based immunoassay was used for rapid and quantitative analysis of serological COVID-19 antibody, showing a path to point-of-care research with a portable detection instrument. This biosensing platform possesses the promising potential to be further extended for multiplexed detection of an analyte of interest. 
Table 4. Photonic technique-based sensing platform for viral infection.

\begin{tabular}{|c|c|c|c|c|c|c|}
\hline S. No. & Antigen/Analyte & Bio-Element & Real Sample & Detection Range & LOD & Ref. \\
\hline 1. & Rotavirus & Secondary fluorescent $\mathrm{Ab}$ & - & $\begin{array}{l}6.35 \mu \mathrm{g} \mathrm{mL}^{-1} \text { to } \\
1.27 \mathrm{mg} \mathrm{mL}^{-1}\end{array}$ & $2.54 \mu \mathrm{g} \mathrm{mL}^{-1}$ & [24] \\
\hline 2. & $\begin{array}{l}\text { Epstein-Barr virus } \\
\text { (EBNA-1) protein }\end{array}$ & EBNA-1 Antibody & PBS & $0.0-10.0 \mu \mathrm{g} \mathrm{mL}^{-1}$ & $\begin{array}{c}1.0 \times \\
10^{-3} \mu \mathrm{g} \mathrm{mL}^{-1}\end{array}$ & [22] \\
\hline 3. & HIV-1 & Antibody & $\begin{array}{c}\text { PBS } \\
\text { Plasma }\end{array}$ & $\begin{array}{l}10^{4}-10^{8} \text { copies } \mathrm{mL}^{-1} \\
10^{2}-10^{7} \text { copies } \mathrm{mL}^{-1}\end{array}$ & - & [65] \\
\hline 4. & DENV E Protein & Antibody & BSA/PBS & $1.0 \mathrm{pM}-1.0 \mathrm{nM}$ & $1.0 \mathrm{pM}$ & [207] \\
\hline 5. & Influenza Virus & Antibody & Human Saliva & $1 \mathrm{pg} \mathrm{mL}^{-1}-100 \mathrm{ng} \mathrm{mL}^{-1}$ & $1.0 \mathrm{ng} \mathrm{mL}^{-1}$ & [23] \\
\hline 6. & SARS-CoV-2 & Antibody & Human Serum & - & $26.7 \mathrm{ng} \mathrm{mL}^{-1}$ & [208] \\
\hline 7. & $\begin{array}{c}\text { Human Papillomavirus } \\
\text { virus-like particles (VLPs) }\end{array}$ & Antibody & $\begin{array}{c}\text { Buffer and Serum } \\
(10 \%)\end{array}$ & $0.70-5.80 \mathrm{nM}$ & $1.5 \mathrm{nM}$ & [209] \\
\hline 8. & Rotavirus & Rotavirus Antibody & Water & $10^{2}-10^{5} \mathrm{PFU} / \mathrm{mL}$ & $<10^{3} \mathrm{PFU} / \mathrm{mL}$ & [210] \\
\hline
\end{tabular}

\section{Conclusions and Future Perspectives}

This review highlighted the current trends in optical biosensors and their ability for virus detection such as COVID-19, MERS, SARS, Influenza, Hepatitis, HIV, HPV, Zika, Herpes, and Dengue virus. A brief account of viral molecular structure, disease symptoms, the gold standard of viral diagnostics, and the magnitude of infection caused was mentioned in the introduction section. Later, various biomarkers for viral detection, such as DNA, RNA, peptides, and antibodies, were discussed. An overview of the state of the art for viral diagnostics and sensor development has been discussed. Based on the available literature, the demand for novel biosensors which can match the sensitivity and selectivity of the conventional nucleic acid tests is in high order. Nanomaterial-based biosensors present ideal alternatives due to their advancement in design and fabrication methods, high selectivity, low sensitivity, and good reproducibility. Any biosensor developed for viral disease (COVID-19) and setting for future viral outbreaks must be readily accessible, affordable, and ideally used either as an at-home test or with minimal sample preparation. Optical biosensors provide additional and alternate testing methods that can generate results at a much quicker rate than the tests currently being used for COVID-19 testing.

Author Contributions: The workflow and structure of review was conceptualized by A.S., R.K.M., K.Y.G. and J.L.M. The different section of review was written by A.S., M.A.M., S.T. and S.K., Z.L., R.N. and L.A.S. contributed in interpreting the relevant literature and intellectual content. L.A.S. and J.L.M. have been involved in drafting the manuscript by providing expert opinion in different section. The draft was finalized by A.S. and S.T. and approved by R.K.M., K.Y.G. and J.L.M. All authors have read and agreed to the published version of the manuscript.

Funding: This research received no external funding.

Institutional Review Board Statement: Not applicable.

Informed Consent Statement: Not applicable.

Data Availability Statement: Not applicable.

Acknowledgments: A.S. would like to acknowledge the SGT University Grammarly software and search engine. K.Y.G. would like to thank the support received from the Department of NanoEngineering, University of California San Diego, USA.

Conflicts of Interest: The authors declare no conflict of interest. 


\section{References}

1. Carter, M.J. Enterically infecting viruses: Pathogenicity, transmission and significance for food and waterborne infection. J. Appl. Microbiol. 2005, 98, 1354-1380. [CrossRef] [PubMed]

2. Maal-Bared, R.; Brisolara, K.; Munakata, N.; Bibby, K.; Gerba, C.; Sobsey, M.; Schaefer, S.; Swift, J.; Gary, L.; Sherchan, S.; et al. Implications of SARS-CoV-2 on current and future operation and management of wastewater systems. Water Environ. Res. 2021, 93, 502-515. [CrossRef] [PubMed]

3. Goud, K.Y.; Reddy, K.K.; Khorshed, A.; Kumar, V.S.; Mishra, R.K.; Oraby, M.; Ibrahim, A.H.; Kim, H.; Gobi, K.V. Electrochemical diagnostics of infectious viral diseases: Trends and challenges. Biosens. Bioelectron. 2021, 180, 113112. [CrossRef] [PubMed]

4. Shah, J.; Wilkins, E. Electrochemical Biosensors for Detection of Biological Warfare Agents. Electroanalysis 2003, 15, 157-167. [CrossRef]

5. Diemer, G.S.; Stedman, K.M. A novel virus genome discovered in an extreme environment suggests recombination between unrelated groups of RNA and DNA viruses. Biol. Direct. 2012, 7, 13. [CrossRef]

6. Tram, D.T.N.; Wang, H.; Sugiarto, S.; Li, T.; Ang, W.H.; Lee, C.; Pastorin, G. Advances in nanomaterials and their applications in point of care (POC) devices for the diagnosis of infectious diseases. Biotechnol. Adv. 2016, 34, 1275-1288. [CrossRef]

7. Kaushik, A.; Tiwari, S.; Jayant, R.; Vashist, A.; Nikkhah-Moshaie, R.; El-Hage, N.; Nair, M. Electrochemical Biosensors for Early Stage Zika Diagnostics. Trends Biotechnol. 2016, 35, 308-317. [CrossRef]

8. Corstjens, P.L.A.M.; Abrams, W.R.; Malamud, D. Saliva and viral infections. Periodontology 2000 2016, 70, 93-110. [CrossRef]

9. Weekly Epidemiological Update on COVID-19. 25 May 2021. Available online: https://www.who.int/publications/m/item/ weekly-epidemiological-update-on-covid-19---25-may-2021 (accessed on 26 May 2021).

10. Campuzano, S.; Yáñez-Sedeño, P.; Pingarrón, J.M. Electrochemical Biosensing for the Diagnosis of Viral Infections and Tropical Diseases. ChemElectroChem 2017, 4, 753-777. [CrossRef]

11. Guliy, O.I.; Zaitsev, B.D.; Larionova, O.S.; Borodina, I.A. Virus Detection Methods and Biosensor Technologies. Biophysics 2019, 64, 890-897. [CrossRef]

12. Katsarou, K.; Bardani, E.; Kallemi, P.; Kalantidis, K. Viral Detection: Past, Present, and Future. BioEssays 2019, 41, 1900049. [CrossRef] [PubMed]

13. Faria, A.M.; Mazon, T. Early diagnosis of Zika infection using a $\mathrm{ZnO}$ nanostructures-based rapid electrochemical biosensor. Talanta 2019, 203, 153-160. [CrossRef] [PubMed]

14. Faria, H.A.M.; Zucolotto, V. Label-free electrochemical DNA biosensor for zika virus identification. Biosens. Bioelectron. 2019, 131, 149-155. [CrossRef]

15. Metzgar, D.; Sampath, R.; Rounds, M.A.; Ecker, D.J. The value and validation of broad spectrum biosensors for diagnosis and biodefense. Virulence 2013, 4, 752-758. [CrossRef] [PubMed]

16. Sharma, A.; Tiwari, S.; Deb, M.K.; Marty, J.L. Severe acute respiratory syndrome coronavirus-2 (SARS-CoV-2): A global pandemic and treatment strategies. Int. J. Antimicrob. Agents 2020, 56, 106054. [CrossRef]

17. Kim, H.-M.; Uh, M.; Jeong, D.H.; Lee, H.-Y.; Park, J.-H.; Lee, S.-K. Localized surface plasmon resonance biosensor using nanopatterned gold particles on the surface of an optical fiber. Sens. Actuators B Chem. 2019, 280, 183-191. [CrossRef]

18. Park, T.J.; Hyun, M.S.; Lee, H.J.; Lee, S.Y.; Ko, S. A self-assembled fusion protein-based surface plasmon resonance biosensor for rapid diagnosis of severe acute respiratory syndrome. Talanta 2009, 79, 295-301. [CrossRef]

19. Chang, Y.; Huang, J.C.; Su, L.; Chen, Y.A.; Chen, C.; Chou, C. Localized surface plasmon coupled fluorescence fiber-optic biosensor for severe acute respiratory syndrome coronavirus nucleocapsid protein detection. In Proceedings of the 200914 th OptoElectronics and Communications Conference, Hong Kong, China, 13-17 July 2009; pp. 1-2.

20. Campbell, D.P. Interferometric Biosensors. In Principles of Bacterial Detection: Biosensors, Recognition Receptors and Microsystems; Zourob, M., Elwary, S., Turner, A., Eds.; Springer: New York, NY, USA, 2008; pp. 169-211.

21. Guider, R.; Gandolfi, D.; Chalyan, T.; Pasquardini, L.; Samusenko, A.; Pederzolli, C.; Pucker, G.; Pavesi, L. Sensitivity and Limit of Detection of biosensors based on ring resonators. Sens. Bio-Sens. Res. 2015, 6, 99-102. [CrossRef]

22. Chen, Y.-T.; Liao, Y.-Y.; Chen, C.-C.; Hsiao, H.-H.; Huang, J.-J. Surface plasmons coupled two-dimensional photonic crystal biosensors for Epstein-Barr virus protein detection. Sens. Actuators B Chem. 2019, 291, 81-88. [CrossRef]

23. Endo, T.; Ozawa, S.; Okuda, N.; Yanagida, Y.; Tanaka, S.; Hatsuzawa, T. Reflectometric detection of influenza virus in human saliva using nanoimprint lithography-based flexible two-dimensional photonic crystal biosensor. Sens. Actuators B Chem. 2010, 148, 269-276. [CrossRef]

24. Maeng, B.; Park, Y.; Park, J. Direct label-free detection of Rotavirus using a hydrogel based nanoporous photonic crystal. RSC Adv. 2016, 6, 7384-7390. [CrossRef]

25. Huang, J.C.; Chang, Y.F.; Chen, K.H.; Su, L.C.; Lee, C.W.; Chen, C.C.; Chen, Y.M.; Chou, C. Detection of severe acute respiratory syndrome (SARS) coronavirus nucleocapsid protein in human serum using a localized surface plasmon coupled fluorescence fiber-optic biosensor. Biosens. Bioelectron. 2009, 25, 320-325. [CrossRef]

26. Dutta, A. Brief Review on Integrated Planar Waveguide-Based Optical Sensor. In Planar Waveguide Optical Sensors: From Theory to Applications; Springer International Publishing: Cham, Switzerland, 2016; pp. 9-69.

27. Martinez, J.S.; Grace, W.K.; Grace, K.M.; Hartman, N.; Swanson, B.I. Pathogen detection using single mode planar optical waveguides. J. Mater. Chem. 2005, 15, 4639-4647. [CrossRef] 
28. Pospíšilová, M.; Kuncová, G.; Trögl, J. Fiber-Optic Chemical Sensors and Fiber-Optic Bio-Sensors. Sensors 2015, 15, $25208-25259$. [CrossRef]

29. Keighron, J.; Ewing, A.; Cans, A.-S. Analytical tools to monitor exocytosis: A focus on new fluorescent probes and methods. Analyst 2012, 137, 1755-1763. [CrossRef]

30. Sharma, A.; Hayat, A.; Mishra, R.K.; Catanante, G.; Bhand, S.; Marty, J.L. Titanium Dioxide Nanoparticles (TiO 2 ) Quenching Based Aptasensing Platform: Application to Ochratoxin A Detection. Toxins 2015, 7, 3771-3784. [CrossRef] [PubMed]

31. Peltomaa, R.; Glahn-Martínez, B.; Benito-Peña, E.; Moreno-Bondi, M.C. Optical Biosensors for Label-Free Detection of Small Molecules. Sensors 2018, 18, 4126. [CrossRef]

32. Sharma, A.; Khan, R.; Catanante, G.; Sherazi, T.A.; Bhand, S.; Hayat, A.; Marty, J.L. Designed Strategies for Fluorescence-Based Biosensors for the Detection of Mycotoxins. Toxins 2018, 10, 197. [CrossRef]

33. Carrascosa, L.G.; Huertas, C.S.; Lechuga, L.M. Prospects of optical biosensors for emerging label-free RNA analysis. TrAC Trends Anal. Chem. 2016, 80, 177-189. [CrossRef]

34. Damborský, P.; Švitel, J.; Katrlík, J. Optical biosensors. Essays Biochem. 2016, 60, 91-100. [CrossRef] [PubMed]

35. Maddali, H.; Miles, C.E.; Kohn, J.; O'Carroll, D.M. Optical Biosensors for Virus Detection: Prospects for SARS-CoV-2/COVID-19. Chembiochem A Eur. J. Chem. Biol. 2020, 22, 1176-1189. [CrossRef]

36. Sharma, A.; Hayat, A.; Mishra, R.K.; Catanante, G.; Shahid, S.A.; Bhand, S.; Marty, J.L. Design of a fluorescence aptaswitch based on the aptamer modulated nano-surface impact on the fluorescence particles. RSC Adv. 2016, 6, 65579-65587. [CrossRef]

37. Mokhtarzadeh, A.; Eivazzadeh-Keihan, R.; Pashazadeh, P.; Hejazi, M.; Gharaatifar, N.; Hasanzadeh, M.; Baradaran, B.; de la Guardia, M. Nanomaterial-based biosensors for detection of pathogenic virus. TrAC Trends Anal. Chem. 2017, 97, 445-457. [CrossRef]

38. Fehr, A.R.; Perlman, S. Coronaviruses: An overview of their replication and pathogenesis. Methods Mol. Biol. 2015, 1282, 1-23. [CrossRef]

39. Paules, C.I.; Marston, H.D.; Fauci, A.S. Coronavirus Infections-More Than Just the Common Cold. JAMA 2020, 323, 707-708. [CrossRef] [PubMed]

40. Olwenyi, O.A.; Dyavar, S.R.; Acharya, A.; Podany, A.T.; Fletcher, C.V.; Ng, C.L.; Reid, S.P.; Byrareddy, S.N. Immuno-epidemiology and pathophysiology of coronavirus disease 2019 (COVID-19). J. Mol. Med. 2020, 98, 1369-1383. [CrossRef]

41. Cucinotta, D.; Vanelli, M. WHO Declares COVID-19 a Pandemic. Acta Biomed. 2020, 91, 157-160. [CrossRef] [PubMed]

42. Centers for Disease Control and Prevention. COVID-19 Overview and Infection Prevention and Control Priorities in Non-Us Healthcare Settings. 2020. Available online: https:/ /www.cdc.gov/coronavirus/2019-ncov/hcp/non-us-settings/overview/ index.html (accessed on 26 May 2021).

43. Archila, P.A.; Danies, G.; Molina, J.; Truscott de Mejía, A.-M.; Restrepo, S. Towards Covid-19 Literacy: Investigating the Literacy Levels of University Students in Colombia. Sci. Educ. 2021, 30, 785-808. [CrossRef]

44. Carlos, W.G.; Dela Cruz, C.S.; Cao, B.; Pasnick, S.; Jamil, S. Novel Wuhan (2019-nCoV) Coronavirus. Am. J. Respir. Crit. Care Med. 2020, 201, P7-P8. [CrossRef] [PubMed]

45. Liu, H.; Chen, S.; Liu, M.; Nie, H.; Lu, H. Comorbid Chronic Diseases are Strongly Correlated with Disease Severity among COVID-19 Patients: A Systematic Review and Meta-Analysis. Aging Dis. 2020, 11, 668-678. [CrossRef] [PubMed]

46. Mertz, D.; Kim, T.H.; Johnstone, J.; Lam, P.P.; Science, M.; Kuster, S.P.; Fadel, S.A.; Tran, D.; Fernandez, E.; Bhatnagar, N.; et al. Populations at risk for severe or complicated influenza illness: Systematic review and meta-analysis. BMJ $2013,347, \mathrm{f} 5061$. [CrossRef] [PubMed]

47. Ludvigsson, J.F. Systematic review of COVID-19 in children shows milder cases and a better prognosis than adults. Acta Paediatr. 2020, 109, 1088-1095. [CrossRef] [PubMed]

48. Funari, R.; Chu, K.-Y.; Shen, A.Q. Detection of antibodies against SARS-CoV-2 spike protein by gold nanospikes in an optomicrofluidic chip. Biosens. Bioelectron. 2020, 169, 112578. [CrossRef] [PubMed]

49. Uddin, S.M.A.; Chowdhury, S.S.; Kabir, E. Numerical Analysis of a Highly Sensitive Surface Plasmon Resonance Sensor for SARS-CoV-2 Detection. Plasmonics 2021, 16, 2025-2037. [CrossRef] [PubMed]

50. Murugan, D.; Bhatia, H.; Sai, V.V.R.; Satija, J. P-FAB: A Fiber-Optic Biosensor Device for Rapid Detection of COVID-19. Trans. Indian Natl. Acad. Eng. 2020, 5, 211-215. [CrossRef]

51. Zumla, A.; Hui, D.S.; Perlman, S. Middle East respiratory syndrome. Lancet 2015, 386, 995-1007. [CrossRef]

52. Ramadan, N.; Shaib, H. Middle East respiratory syndrome coronavirus (MERS-CoV): A review. Germs 2019, 9, 35-42. [CrossRef]

53. Elkholy, A.A.; Grant, R.; Assiri, A.; Elhakim, M.; Malik, M.R.; Van Kerkhove, M.D. MERS-CoV infection among healthcare workers and risk factors for death: Retrospective analysis of all laboratory-confirmed cases reported to WHO from 2012 to 2 June 2018. J. Infect. Public Health 2020, 13, 418-422. [CrossRef]

54. Al-Tawfiq, J.A.; Gautret, P. Asymptomatic Middle East Respiratory Syndrome Coronavirus (MERS-CoV) infection: Extent and implications for infection control: A systematic review. Travel Med. Infect. Dis. 2019, 27, 27-32. [CrossRef]

55. Layqah, L.A.; Eissa, S. An electrochemical immunosensor for the corona virus associated with the Middle East respiratory syndrome using an array of gold nanoparticle-modified carbon electrodes. Mikrochim. Acta 2019, 186, 224. [CrossRef]

56. Sun, Y.; Zhang, H.; Shi, J.; Zhang, Z.; Gong, R. Identification of a Novel Inhibitor against Middle East Respiratory Syndrome Coronavirus. Viruses 2017, 9, 255. [CrossRef] 
57. Kilianski, A.; Mielech, A.M.; Deng, X.; Baker, S.C. Assessing activity and inhibition of Middle East respiratory syndrome coronavirus papain-like and 3C-like proteases using luciferase-based biosensors. J. Virol. 2013, 87, 11955-11962. [CrossRef] [PubMed]

58. Kim, H.; Park, M.; Hwang, J.; Kim, J.H.; Chung, D.-R.; Lee, K.-S.; Kang, M. Development of Label-Free Colorimetric Assay for MERS-CoV Using Gold Nanoparticles. ACS Sens. 2019, 4, 1306-1312. [CrossRef] [PubMed]

59. Teengam, P.; Siangproh, W.; Tuantranont, A.; Vilaivan, T.; Chailapakul, O.; Henry, C.S. Multiplex Paper-Based Colorimetric DNA Sensor Using Pyrrolidinyl Peptide Nucleic Acid-Induced AgNPs Aggregation for Detecting MERS-CoV, MTB, and HPV Oligonucleotides. Anal. Chem. 2017, 89, 5428-5435. [CrossRef] [PubMed]

60. Sharp, P.M.; Hahn, B.H. The evolution of HIV-1 and the origin of AIDS. Philos. Trans. R. Soc. B Biol. Sci. 2010, 365, $2487-2494$. [CrossRef]

61. Monaco, C.L.; Gootenberg, D.B.; Zhao, G.; Handley, S.A.; Ghebremichael, M.S.; Lim, E.S.; Lankowski, A.; Baldridge, M.T.; Wilen, C.B.; Flagg, M.; et al. Altered Virome and Bacterial Microbiome in Human Immunodeficiency Virus-Associated Acquired Immunodeficiency Syndrome. Cell Host Microbe 2016, 19, 311-322. [CrossRef]

62. Zulfiqar, H.F.; Javed, A.; Sumbal; Afroze, B.; Ali, Q.; Akbar, K.; Nadeem, T.; Rana, M.A.; Nazar, Z.A.; Nasir, I.A.; et al. HIV Diagnosis and Treatment through Advanced Technologies. Front. Public Health 2017, 5, 32. [CrossRef]

63. Schmidt, B.; Scott, I.; Whitmore, R.; Foster, H.; Fujimura, S.; Schmitz, J.; Levy, J. Low-level HIV infection of plasmacytoid dendritic cells: Onset of cytopathic effects and cell death after PDC maturation. Virology 2004, 329, 280-288. [CrossRef]

64. Ostermann, J.; Njau, B.; Hobbie, A.; Mtuy, T.; Masaki, M.L.; Shayo, A.; van Zwetselaar, M.; Masnick, M.; Flaherty, B.; Brown, D.S.; et al. Using discrete choice experiments to design interventions for heterogeneous preferences: Protocol for a pragmatic randomised controlled trial of a preference-informed, heterogeneity-focused, HIV testing offer for high-risk populations. BMJ Open 2020, 10, e039313. [CrossRef]

65. Shafiee, H.; Lidstone, E.A.; Jahangir, M.; Inci, F.; Hanhauser, E.; Henrich, T.J.; Kuritzkes, D.R.; Cunningham, B.T.; Demirci, U. Nanostructured Optical Photonic Crystal Biosensor for HIV Viral Load Measurement. Sci. Rep. 2014, 4, 4116. [CrossRef]

66. Farzin, L.; Shamsipur, M.; Samandari, L.; Sheibani, S. HIV biosensors for early diagnosis of infection: The intertwine of nanotechnology with sensing strategies. Talanta 2020, 206, 120201. [CrossRef]

67. Patel, S. Hepatitis: Review. SA Pharm. J. 2015, 82, 20-23. [CrossRef]

68. Czaja, A.J. Drug-Induced Autoimmune-Like Hepatitis. Dig. Dis. Sci. 2011, 56, 958-976. [CrossRef]

69. Strader, D.B.; Wright, T.; Thomas, D.L.; Seeff, L.B. Diagnosis, management, and treatment of hepatitis C. Hepatology 2004, 39, 1147-1171. [CrossRef]

70. Zuckerman, A. Chapter 70: Hepatitis viruses. In Medical Microbiology, 4th ed.; University of Texas Medical Branch: Galveston, TX, USA, 1996.

71. Dalton, H.R.; Bendall, R.; Ijaz, S.; Banks, M. Hepatitis E: An emerging infection in developed countries. Lancet Infect. Dis. 2008, 8, 698-709. [CrossRef]

72. EFSA Panel on Biological Hazards (BIOHAZ); Ricci, A.; Allende, A.; Bolton, D.; Chemaly, M.; Davies, R.; Fernandez Escamez, P.S.; Herman, L.; Koutsoumanis, K.; Lindqvist, R.; et al. Public health risks associated with hepatitis E virus (HEV) as a food-borne pathogen. EFSA J. 2017, 15, e04886. [CrossRef]

73. Mukomolov, S. Viral Hepatitis: Selected Issues of Pathogenesis and Diagnostics; BoD-Books on Demand; IntechOpen Limited: London, UK, 2011.

74. Dakl, A.A.A.; Alnuaimy, W.A. Epidemiology of Hepatitis B and C in Al-Muthanna Province. Prof. RK Sharma 2020, 14, 419.

75. Dionne-Odom, J.; Tita, A.T.N.; Silverman, N.S. \#38: Hepatitis B in pregnancy screening, treatment, and prevention of vertical transmission. Am. J. Obstet. Gynecol. 2016, 214, 6-14. [CrossRef]

76. Pallavi, K.; Sravani, D.; Durga, S.; Durga, P.; Pavan, P.; Babu, P.; Raviteja, K. Hepatitis review on current and future scenario. J. Silico Vitr. Pharm. 2017, 3, 1-5.

77. Jimenez, A.; Sharafeldin, N.; El-Hoseiny, M.; El-Daly, M.; Abdel-Hamid, M.; Aidi, S.; Sultan, Y.; El-Sayed, N.; Mohamed, M.; Fontanet, A. Community transmission of hepatitis B virus in Egypt: Results from a case-control study in Greater Cairo. Int. J. Epidemiol. 2009, 38, 757-765. [CrossRef] [PubMed]

78. Shepard, C.W.; Simard, E.P.; Finelli, L.; Fiore, A.E.; Bell, B.P. Hepatitis B Virus Infection: Epidemiology and Vaccination. Epidemiol. Rev. 2006, 28, 112-125. [CrossRef] [PubMed]

79. Stasi, C.; Silvestri, C.; Voller, F. Update on Hepatitis C Epidemiology: Unaware and Untreated Infected Population Could Be the Key to Elimination. SN Compr. Clin. Med. 2020, 2, 2808-2815. [CrossRef] [PubMed]

80. Hall, E.W.; Rosenberg, E.S.; Sullivan, P.S. Estimates of state-level chronic hepatitis C virus infection, stratified by race and sex, United States, 2010. BMC Infect. Dis. 2018, 18, 224. [CrossRef] [PubMed]

81. Zibbell, J.E.; Iqbal, K.; Patel, R.C.; Suryaprasad, A.; Sanders, K.J.; Moore-Moravian, L.; Serrecchia, J.; Blankenship, S.; Ward, J.W.; Holtzman, D. Increases in hepatitis C virus infection related to injection drug use among persons aged $\leq 30$ years-Kentucky, Tennessee, Virginia, and West Virginia, 2006-2012. MMWR Morb Mortal Wkly. Rep. 2015, 64, 453-458. [PubMed]

82. Wedemeyer, H.; Manns, M.P. Epidemiology, pathogenesis and management of hepatitis D: Update and challenges ahead. Nat. Rev. Gastroenterol. Hepatol. 2010, 7, 31. [CrossRef]

83. Hsieh, T.-H.; Liu, C.-J.; Chen, D.-S.; Chen, P.-J. Natural Course and Treatment of Hepatitis D Virus Infection. J. Formos. Med. Assoc. 2006, 105, 869-881. [CrossRef] 
84. Chen, H.-Y.; Shen, D.-T.; Ji, D.-Z.; Han, P.-C.; Zhang, W.-M.; Ma, J.-F.; Chen, W.-S.; Goyal, H.; Pan, S.; Xu, H.-G. Prevalence and burden of hepatitis D virus infection in the global population: A systematic review and meta-analysis. Gut 2019, 68, 512-521. [CrossRef]

85. Wu, T.; Li, X.; Fu, Y.; Ding, X.; Li, Z.; Zhu, G.; Fan, J. A highly sensitive and selective fluorescence biosensor for hepatitis C virus DNA detection based on $\delta$-FeOOH and exonuclease III-assisted signal amplification. Talanta 2020, 209, 120550. [CrossRef]

86. Acosta, E.G.; Castilla, V.; Damonte, E.B. Functional entry of dengue virus into Aedes albopictus mosquito cells is dependent on clathrin-mediated endocytosis. J. Gen. Virol. 2008, 89, 474-484. [CrossRef]

87. Thomas, L.; Verlaeten, O.; Cabié, A.; Kaidomar, S.P.; Moravie, V.; Martial, J.; Najioullah, F.; Plumelle, Y.; Fonteau, C.; Dussart, P.; et al. Influence of the Dengue Serotype, Previous Dengue Infection, and Plasma Viral Load on Clinical Presentation and Outcome During a Dengue-2 and Dengue-4 Co-Epidemic. Am. J. Trop. Med. Hyg. Am. J. Trop. Med. Hyg. 2008, 78, 990-998. [CrossRef]

88. Crill, W.D.; Hughes, H.R.; Delorey, M.J.; Chang, G.-J.J. Humoral Immune Responses of Dengue Fever Patients Using EpitopeSpecific Serotype-2 Virus-Like Particle Antigens. PLoS ONE 2009, 4, e4991. [CrossRef] [PubMed]

89. Centers for Disease Control and Prevention. Available online: https://www.cdc.gov/dengue/about/index.html (accessed on 20 May 2021).

90. Sanyaolu, A.; Okorie, C.; Badaru, O.; Adetona, K.; Ahmed, M.; Akanbi, O.; Foncham, J.; Kadavil, S.; Likaj, L.; Raza, S. Global epidemiology of dengue hemorrhagic fever: An update. J. Hum. Virol. Retrovirol. 2017, 5, 00179. [CrossRef]

91. Li, Y.-T.; Linster, M.; Mendenhall, I.H.; Su, Y.C.F.; Smith, G.J.D. Avian influenza viruses in humans: Lessons from past outbreaks. Br. Med. Bull. 2019, 132, 81-95. [CrossRef] [PubMed]

92. Capua, I.; Alexander, D.J. Avian influenza and human health. Acta Trop. 2002, 83, 1-6. [CrossRef]

93. Mustapha Kamil, Y.; Al-Rekabi, S.H.; Yaacob, M.H.; Syahir, A.; Chee, H.Y.; Mahdi, M.A.; Abu Bakar, M.H. Detection of dengue using PAMAM dendrimer integrated tapered optical fiber sensor. Sci. Rep. 2019, 9, 13483. [CrossRef] [PubMed]

94. Omar, N.A.S.; Fen, Y.W.; Abdullah, J.; Chik, C.E.N.C.E.; Mahdi, M.A. Development of an optical sensor based on surface plasmon resonance phenomenon for diagnosis of dengue virus E-protein. Sens. Bio-Sens. Res. 2018, 20, 16-21. [CrossRef]

95. Pashchenko, O.; Shelby, T.; Banerjee, T.; Santra, S. A Comparison of Optical, Electrochemical, Magnetic, and Colorimetric Point-of-Care Biosensors for Infectious Disease Diagnosis. ACS Infect. Dis. 2018, 4, 1162-1178. [CrossRef]

96. Dimitrov, D.S. Virus entry: Molecular mechanisms and biomedical applications. Nat. Rev. Microbiol. 2004, 2, 109-122. [CrossRef]

97. Kermali, M.; Khalsa, R.K.; Pillai, K.; Ismail, Z.; Harky, A. The role of biomarkers in diagnosis of COVID-19—A systematic review. Life Sci. 2020, 254, 117788. [CrossRef]

98. Ponti, G.; Maccaferri, M.; Ruini, C.; Tomasi, A.; Ozben, T. Biomarkers associated with COVID-19 disease progression. Crit Rev. Clin. Lab. Sci. 2020, 57, 389-399. [CrossRef]

99. Asif, M.; Ajmal, M.; Ashraf, G.; Muhammad, N.; Aziz, A.; Iftikhar, T.; Wang, J.; Liu, H. The role of biosensors in coronavirus disease-2019 outbreak. Curr. Opin. Electrochem. 2020, 23, 174-184. [CrossRef]

100. Stol, K.; Nijman, R.G.; van Herk, W.; van Rossum, A.M.C. Biomarkers for Infection in Children: Current Clinical Practice and Future Perspectives. Pediatric Infect. Dis. J. 2019, 38, S7-S13. [CrossRef]

101. Kotru, S.; Klimuntowski, M.; Ridha, H.; Uddin, Z.; Askhar, A.A.; Singh, G.; Howlader, M.M.R. Electrochemical sensing: A prognostic tool in the fight against COVID-19. Trends Anal. Chem. 2021, 136, 116198. [CrossRef] [PubMed]

102. Qureshi, A.; Niazi, J.H. Biosensors for detecting viral and bacterial infections using host biomarkers: A review. Analyst 2021, 145, 7825-7848. [CrossRef] [PubMed]

103. Kapasi, A.J.; Dittrich, S.; González, I.J.; Rodwell, T.C. Host Biomarkers for Distinguishing Bacterial from Non-Bacterial Causes of Acute Febrile Illness: A Comprehensive Review. PLoS ONE 2016, 11, e0160278. [CrossRef] [PubMed]

104. Bhuiyan, M.U.; Blyth, C.C.; West, R.; Lang, J.; Rahman, T.; Granland, C.; de Gier, C.; Borland, M.L.; Thornton, R.B.; Kirkham, L.-A.S.; et al. Combination of clinical symptoms and blood biomarkers can improve discrimination between bacterial or viral community-acquired pneumonia in children. BMC Pulm. Med. 2019, 19, 71. [CrossRef]

105. Mayer-Scholl, A.; Averhoff, P.; Zychlinsky, A. How do neutrophils and pathogens interact? Curr. Opin. Microbiol. 2004, 7, 62-66. [CrossRef]

106. Prilutsky, D.; Shneider, E.; Shefer, A.; Rogachev, B.; Lobel, L.; Last, M.; Marks, R.S. Differentiation between Viral and Bacterial Acute Infections Using Chemiluminescent Signatures of Circulating Phagocytes. Anal. Chem. 2011, 83, 4258-4265. [CrossRef]

107. Pepys, M.B.; Hirschfield, G.M. C-reactive protein: A critical update. J. Clin. Investig. 2003, 111, 1805-1812. [CrossRef]

108. Wacker, C.; Prkno, A.; Brunkhorst, F.M.; Schlattmann, P. Procalcitonin as a diagnostic marker for sepsis: A systematic review and meta-analysis. Lancet Infect. Dis. 2013, 13, 426-435. [CrossRef]

109. Zhang, J.-M.; An, J. Cytokines, Inflammation, and Pain. Int. Anesthesiol. Clin. 2007, 45, 27-37. [CrossRef]

110. Kumar, S.; Tripathy, S.; Jyoti, A.; Singh, S.G. Recent advances in biosensors for diagnosis and detection of sepsis: A comprehensive review. Biosens. Bioelectron. 2019, 124-125, 205-215. [CrossRef]

111. Angulo, J.; Martínez-Valdebenito, C.; Marco, C.; Galeno, H.; Villagra, E.; Vera, L.; Lagos, N.; Becerra, N.; Mora, J.; Bermúdez, A.; et al. Serum levels of interleukin-6 are linked to the severity of the disease caused by Andes Virus. PLOS Negl. Trop. Dis. 2017, 11, e0005757. [CrossRef]

112. Bray, M. Defense against filoviruses used as biological weapons. Antivir. Res. 2003, 57, 53-60. [CrossRef]

113. Krug, R.M. The potential use of influenza virus as an agent for bioterrorism. Antivir. Res. 2003, 57, 147-150. [CrossRef] 
114. Noah, D.L.; Huebner, K.D.; Darling, R.G.; Waeckerle, J.F. The history and threat of biological warfare and terrorism. Emerg. Med. Clin. N. Am. 2002, 20, 255-271. [CrossRef]

115. Daaboul, G.G.; Lopez, C.A.; Yurt, A.; Goldberg, B.B.; Connor, J.H.; Ünlü, M.S. Label-free optical biosensors for virus detection and characterization. IEEE J. Sel. Top. Quantum Electron. 2011, 18, 1422-1433. [CrossRef]

116. Saylan, Y.; Erdem, Ö.; Ünal, S.; Denizli, A. An alternative medical diagnosis method: Biosensors for virus detection. Biosensors 2019, 9, 65. [CrossRef] [PubMed]

117. Sin, M.L.; Mach, K.E.; Wong, P.K.; Liao, J.C. Advances and challenges in biosensor-based diagnosis of infectious diseases. Expert Rev. Mol. Diagn. 2014, 14, 225-244. [CrossRef] [PubMed]

118. Mohamed, M.A. Wearable miniaturized electrochemical sensors: Benefits and challenges. In Electrochemistry: Volume 15; The Royal Society of Chemistry: London, UK, 2019; Volume 15, pp. 147-185.

119. Citartan, M.; Gopinath, S.C.; Tominaga, J.; Tang, T.-H. Label-free methods of reporting biomolecular interactions by optical biosensors. Analyst 2013, 138, 3576-3592. [CrossRef]

120. Gharatape, A.; Yari Khosroushahi, A. Optical biomarker-based biosensors for cancer/infectious disease medical diagnoses. Appl. Immunohistochem. Mol. Morphol. 2019, 27, 278-286. [CrossRef] [PubMed]

121. Dolatabadi, J.E.N.; Mashinchian, O.; Ayoubi, B.; Jamali, A.A.; Mobed, A.; Losic, D.; Omidi, Y.; de la Guardia, M. Optical and electrochemical DNA nanobiosensors. TrAC Trends Anal. Chem. 2011, 30, 459-472. [CrossRef]

122. Antiochia, R. Developments in biosensors for CoV detection and future trends. Biosens. Bioelectron. 2021, 173, 112777. [CrossRef] [PubMed]

123. Abdulhalim, I.; Zourob, M.; Lakhtakia, A. Surface plasmon resonance for biosensing: A mini-review. Electromagnetics 2008, 28, 214-242. [CrossRef]

124. Sami, M.A.; Wagner, K.; Parikh, P.; Hassan, U. Smartphone Based Microfluidic Biosensor for Leukocyte Quantification at the Point-of-Care. In Proceedings of the 2019 IEEE Healthcare Innovations and Point of Care Technologies,(HI-POCT), Bethesda, MD, USA, 20-22 November 2019; pp. 119-122.

125. Mukundan, H.; Anderson, A.S.; Grace, W.K.; Grace, K.M.; Hartman, N.; Martinez, J.S.; Swanson, B.I. Waveguide-Based Biosensors for Pathogen Detection. Sensors 2009, 9, 5783-5809. [CrossRef]

126. Choi, K.; Kim, J.Y.; Ahn, J.H.; Choi, J.M.; Im, M.; Choi, Y.K. Integration of field effect transistor-based biosensors with a digital microfluidic device for a lab-on-a-chip application. Lab. Chip 2012, 12, 1533-1539. [CrossRef]

127. Kim, J.; Campbell, A.S.; de Ávila, B.E.-F.; Wang, J. Wearable biosensors for healthcare monitoring. Nat. Biotechnol. 2019, 37, 389-406. [CrossRef]

128. Chen, S.; Chen, L.; Tan, J.; Chen, J.; Du, L.; Sun, T.; Shen, J.; Chen, K.; Jiang, H.; Shen, X. Severe acute respiratory syndrome coronavirus 3C-like proteinase $\mathrm{N}$ terminus is indispensable for proteolytic activity but not for enzyme dimerization: Biochemical and thermodynamic investigation in conjunction with molecular dynamics simulations. J. Biol. Chem. 2005, 280, 164-173. [CrossRef]

129. Guo, X. Surface plasmon resonance based biosensor technique: A review. J. Biophotonics 2012, 5, 483-501. [CrossRef]

130. Tawil, N.; Sacher, E.; Mandeville, R.; Meunier, M. Surface plasmon resonance detection of E. coli and methicillin-resistant S. aureus using bacteriophages. Biosens. Bioelectron. 2012, 37, 24-29. [CrossRef]

131. Kussrow, A.; Baksh, M.M.; Bornhop, D.J.; Finn, M. Universal sensing by transduction of antibody binding with backscattering interferometry. ChemBioChem 2011, 12, 367-370. [CrossRef]

132. Kussrow, A.; Enders, C.S.; Castro, A.R.; Cox, D.L.; Ballard, R.C.; Bornhop, D.J. The potential of backscattering interferometry as an in vitro clinical diagnostic tool for the serological diagnosis of infectious disease. Analyst 2010, 135, 1535-1537. [CrossRef] [PubMed]

133. Qiu, G.; Gai, Z.; Tao, Y.; Schmitt, J.; Kullak-Ublick, G.A.; Wang, J. Dual-functional plasmonic photothermal biosensors for highly accurate severe acute respiratory syndrome coronavirus 2 detection. ACS Nano 2020, 14, 5268-5277. [CrossRef]

134. Kaja, S.; Hilgenberg, J.D.; Collins, J.L.; Shah, A.A.; Koulen, P.; Wawro, D.D.; Zimmerman, S.; Magnusson, R. Detection of novel biomarkers for ovarian cancer with an optical nanotechnology detection system enabling label-free diagnostics. J. Biomed. Opt. 2012, 17, 081412. [CrossRef]

135. Najeeb, N.; Zhang, Y.; Mellor, C.; Benson, T. Photonic biosensor chip for early-stage cancer diagnosis. In Proceedings of the 2015 17th International Conference on Transparent Optical Networks (ICTON), Budapest, Hungary, 5-9 July 2015; pp. 1-4.

136. Burnett, L.C.; Lunn, G.; Coico, R. Biosafety: Guidelines for working with pathogenic and infectious microorganisms. Curr. Protoc. Microbiol. 2009, 13, Unit 1A.1. [CrossRef]

137. Shi, Y.; Li, Z.; Liu, P.Y.; Nguyen, B.T.T.; Wu, W.; Zhao, Q.; Chin, L.K.; Wei, M.; Yap, P.H.; Zhou, X.; et al. On-Chip Optical Detection of Viruses: A Review. Adv. Photonics Res. 2021, 2, 2000150. [CrossRef] [PubMed]

138. Rosendahl Huber, S.K.; Luimstra, J.J.; van Beek, J.; Hoppes, R.; Jacobi, R.H.J.; Hendriks, M.; Kapteijn, K.; Ouwerkerk, C.; Rodenko, B.; Ovaa, H.; et al. Chemical Modification of Influenza CD8+ T-Cell Epitopes Enhances Their Immunogenicity Regardless of Immunodominance. PLoS ONE 2016, 11, e0156462. [CrossRef] [PubMed]

139. Crux, N.B.; Elahi, S. Human Leukocyte Antigen (HLA) and Immune Regulation: How Do Classical and Non-Classical HLA Alleles Modulate Immune Response to Human Immunodeficiency Virus and Hepatitis C Virus Infections? Front. Immunol. 2017, 8, 832. [CrossRef] 
140. Shrivastav, A.M.; Cvelbar, U.; Abdulhalim, I. A comprehensive review on plasmonic-based biosensors used in viral diagnostics. Commun. Biol. 2021, 4, 70. [CrossRef]

141. Wang, R.; Ongagna-Yhombi, S.Y.; Lu, Z.; Centeno-Tablante, E.; Colt, S.; Cao, X.; Ren, Y.; Cárdenas, W.B.; Mehta, S.; Erickson, D. Rapid Diagnostic Platform for Colorimetric Differential Detection of Dengue and Chikungunya Viral Infections. Anal. Chem. 2019, 91, 5415-5423. [CrossRef]

142. Zhao, V.X.T.; Wong, T.I.; Zheng, X.T.; Tan, Y.N.; Zhou, X. Colorimetric biosensors for point-of-care virus detections. Mater. Sci. Energy Technol. 2020, 3, 237-249. [CrossRef]

143. Aboul-Enein, H.; Stefan, R.-I.; Van Staden, J. Chemiluminescence-Based (Bio)Sensors-An Overview. Crit. Rev. Anal. Chem. 1999, 29, 323-331. [CrossRef]

144. Ozer, T.; Geiss, B.J.; Henry, C.S. Review-Chemical and Biological Sensors for Viral Detection. J. Electrochem. Soc. 2020, 167, 037523. [CrossRef]

145. Choi, Y.; Hwang, J.H.; Lee, S.Y. Recent Trends in Nanomaterials-Based Colorimetric Detection of Pathogenic Bacteria and Viruses. Small Methods 2018, 2, 1700351. [CrossRef]

146. Liu, B.; Zhuang, J.; Wei, G. Recent advances in the design of colorimetric sensors for environmental monitoring. Environ. Sci. Nano 2020, 7, 2195-2213. [CrossRef]

147. VS, A.P.; Joseph, P.; Daniel, K.; Susithra, L.; Kinoshita, T.; Muthusamy, S. Colorimetric sensors for rapid detection of various analytes. Mater. Sci. Eng. C 2017, 78, 1231-1245. [CrossRef]

148. Luo, J.; Dong, W.; Wang, C.; Wen, J.; Xia, Y.; Wang, H.; Ding, H.; Jiang, L.; He, H. Development and Evaluation of a Polydiacetylene Based Biosensor for the Detection of H5 Influenza Virus. J. Virol. Methods 2015, 219, 38-45. [CrossRef]

149. Abdul Rahman, S.; Saadun, R.; Azmi, N.E.; Ariffin, N.; Abdullah, J.; Yusof, N.A.; Sidek, H.; Hajian, R. Label-Free Dengue Detection Utilizing PNA/DNA Hybridization Based on the Aggregation Process of Unmodified Gold Nanoparticles. J. Nanomater. 2014, 2014, 839286. [CrossRef]

150. Kanjanawarut, R.; Su, X. Colorimetric Detection of DNA Using Unmodified Metallic Nanoparticles and Peptide Nucleic Acid Probes. Anal. Chem. 2009, 81, 6122-6129. [CrossRef]

151. Rey, E.G.; O’Dell, D.; Mehta, S.; Erickson, D. Mitigating the Hook Effect in Lateral Flow Sandwich Immunoassays Using Real-Time Reaction Kinetics. Anal. Chem. 2017, 89, 5095-5100. [CrossRef] [PubMed]

152. Sauter, N.K.; Hanson, J.E.; Glick, G.D.; Brown, J.H.; Crowther, R.L.; Park, S.J.; Skehel, J.J.; Wiley, D.C. Binding of influenza virus hemagglutinin to analogs of its cell-surface receptor, sialic acid: Analysis by proton nuclear magnetic resonance spectroscopy and x-ray crystallography. Biochemistry 1992, 31, 9609-9621. [CrossRef] [PubMed]

153. Weis, W.; Brown, J.H.; Cusack, S.; Paulson, J.C.; Skehel, J.J.; Wiley, D.C. Structure of the influenza virus haemagglutinin complexed with its receptor, sialic acid. Nature 1988, 333, 426-431. [CrossRef]

154. Suzuki, T.; Portner, A.; Scroggs, R.; Uchikawa, M.; Koyama, N.; Matsuo, K.; Suzuki, Y.; Takimoto, T. Receptor Specificities of Human Respiroviruses. J. Virol. 2001, 75, 4604-4613. [CrossRef]

155. Lee, C.; Gaston, M.A.; Weiss, A.A.; Zhang, P. Colorimetric viral detection based on sialic acid stabilized goldnanoparticles. Biosens. Bioelectron. 2013, 42, 236-241. [CrossRef]

156. Ahmed, S.R.; Kim, J.; Tran, V.T.; Suzuki, T.; Neethirajan, S.; Lee, J.; Park, E.Y. In situ self-assembly of gold nanoparticles on hydrophilic and hydrophobic substrates for influenza virus-sensing platform. Sci. Rep. 2017, 7, 44495. [CrossRef] [PubMed]

157. Xia, Y.; Chen, Y.; Tang, Y.; Cheng, G.; Yu, X.; He, H.; Cao, G.; Lu, H.; Liu, Z.; Zheng, S.-Y. Smartphone-Based Point-of-Care Microfluidic Platform Fabricated with a ZnO Nanorod Template for Colorimetric Virus Detection. ACS Sens. 2019, 4, 3298-3307. [CrossRef] [PubMed]

158. Mao, X.; Liu, S.; Yang, C.; Liu, F.; Wang, K.; Chen, G. Colorimetric detection of hepatitis B virus (HBV) DNA based on DNA-templated copper nanoclusters. Anal. Chim. Acta 2016, 909, 101-108. [CrossRef] [PubMed]

159. Hu, Y.; Chen, R.; Chen, M.; An, J.; Luo, M.; Lyu, Y.; Hu, N.; Guo, W.; Li, W.; Liu, Y. Magnetic Separation and Enzymatic Catalysis Conjugated Colorimetric Immunosensor for Hepatitis B Surface Antigen Detection. Microchem. J. 2021, 106155. [CrossRef]

160. Mohammed, A.S.; Balapure, A.; Khaja, M.N.; Ganesan, R.; Dutta, J.R. Naked-eye colorimetric detection of HCV RNA mediated by a $5^{\prime}$ UTR-targeted antisense oligonucleotide and plasmonic gold nanoparticles. Analyst 2021, 146, 1569-1578. [CrossRef]

161. González-González, E.; Lara-Mayorga, I.M.; Rodríguez-Sánchez, I.P.; Zhang, Y.S.; Martínez-Chapa, S.O.; Santiago, G.T.-d.; Alvarez, M.M. Colorimetric loop-mediated isothermal amplification (LAMP) for cost-effective and quantitative detection of SARS-CoV-2: The change in color in LAMP-based assays quantitatively correlates with viral copy number. Anal. Methods 2021, 13, 169-178. [CrossRef]

162. Ventura, B.D.; Cennamo, M.; Minopoli, A.; Campanile, R.; Censi, S.B.; Terracciano, D.; Portella, G.; Velotta, R. Colorimetric Test for Fast Detection of SARS-CoV-2 in Nasal and Throat Swabs. ACS Sens. 2020, 5, 3043-3048. [CrossRef]

163. Jeong, J.-P.; Cho, E.; Yun, D.; Kim, T.; Lee, I.-S.; Jung, S. Label-Free Colorimetric Detection of Influenza Antigen Based on an Antibody-Polydiacetylene Conjugate and Its Coated Polyvinylidene Difluoride Membrane. Polymers 2017, 9, 127. [CrossRef] [PubMed]

164. Bhardwaj, J.; Sharma, A.; Jang, J. Vertical flow-based paper immunosensor for rapid electrochemical and colorimetric detection of influenza virus using a different pore size sample pad. Biosens. Bioelectron. 2019, 126, 36-43. [CrossRef] [PubMed]

165. Oh, S.; Kim, J.; Tran, V.T.; Lee, D.K.; Ahmed, S.R.; Hong, J.C.; Lee, J.; Park, E.Y.; Lee, J. Magnetic Nanozyme-Linked Immunosorbent Assay for Ultrasensitive Influenza A Virus Detection. ACS Appl. Mater. Interfaces 2018, 10, 12534-12543. [CrossRef] [PubMed] 
166. Kang, J.; Yeom, G.; Jang, H.; Park, C.-J.; Kim, M.-G. Highly sensitive and universal detection strategy based on a colorimetric assay using target-specific heterogeneous sandwich DNA aptamer. Anal. Chim. Acta 2020, 1123, 73-80. [CrossRef]

167. Li, B.; Yu, Q.; Duan, Y. Fluorescent labels in biosensors for pathogen detection. Crit. Rev. Biotechnol. 2013, 35, 82-93. [CrossRef] [PubMed]

168. Waggoner, A. Fluorescent labels for proteomics and genomics. Curr. Opin. Chem. Biol. 2006, 10, 62-66. [CrossRef]

169. Lu, X.; Dong, X.; Zhang, K.; Han, X.; Fang, X.; Zhang, Y. A gold nanorods-based fluorescent biosensor for the detection of hepatitis $B$ virus DNA based on fluorescence resonance energy transfer. Analyst 2013, 138, 642-650. [CrossRef]

170. Shen, J.; Zhou, Y.; Fu, F.; Xu, H.; Lv, J.; Xiong, Y.; Wang, A. Immunochromatographic assay for quantitative and sensitive detection of hepatitis B virus surface antigen using highly luminescent quantum dot-beads. Talanta 2015, 142, 145-149. [CrossRef]

171. Yang, B.; Gong, H.; Chen, C.; Chen, X.; Cai, C. A virus resonance light scattering sensor based on mussel-inspired molecularly imprinted polymers for high sensitive and high selective detection of Hepatitis A Virus. Biosens. Bioelectron. 2017, 87, 679-685. [CrossRef]

172. Pang, Y.; Rong, Z.; Wang, J.; Xiao, R.; Wang, S. A fluorescent aptasensor for H5N1 influenza virus detection based-on the core-shell nanoparticles metal-enhanced fluorescence (MEF). Biosens. Bioelectron. 2015, 66, 527-532. [CrossRef] [PubMed]

173. Kato, T.; Kawaguchi, A.; Nagata, K.; Hatanaka, K. Development of tetraphenylethylene-based fluorescent oligosaccharide probes for detection of influenza virus. Biochem. Biophys. Res. Commun. 2010, 394, 200-204. [CrossRef]

174. Fukuyama, S.; Katsura, H.; Zhao, D.; Ozawa, M.; Ando, T.; Shoemaker, J.E.; Ishikawa, I.; Yamada, S.; Neumann, G.; Watanabe, S.; et al. Multi-spectral fluorescent reporter influenza viruses (Color-flu) as powerful tools for in vivo studies. Nat. Commun. 2015, 6, 6600. [CrossRef] [PubMed]

175. Yang, S.-P.; Chen, S.-R.; Liu, S.-W.; Tang, X.-Y.; Qin, L.; Qiu, G.-H.; Chen, J.-X.; Chen, W.-H. Platforms Formed from a ThreeDimensional Cu-Based Zwitterionic Metal-Organic Framework and Probe ss-DNA: Selective Fluorescent Biosensors for Human Immunodeficiency Virus 1 ds-DNA and Sudan Virus RNA Sequences. Anal. Chem. 2015, 87, 12206-12214. [CrossRef]

176. Gao, Y.; Han, Y.; Wang, C.; Qiang, L.; Gao, J.; Wang, Y.; Liu, H.; Han, L.; Zhang, Y. Rapid and sensitive triple-mode detection of causative SARS-CoV-2 virus specific genes through interaction between genes and nanoparticles. Anal. Chim. Acta 2021, 1154, 338330. [CrossRef]

177. Zhu, T.; He, J.A.; Chen, W.; Ho, H.P.; Kong, S.K.; Wang, C.; Long, J.; Fong-Chuen Loo, J.; Gu, D. Development of peptide-based chemiluminescence enzyme immunoassay (CLEIA) for diagnosis of dengue virus infection in human. Anal. Biochem. 2018, 556, 112-118. [CrossRef]

178. Jung, H.; Park, S.H.; Lee, J.; Lee, B.; Park, J.; Seok, Y.; Choi, J.-H.; Kim, M.-G.; Song, C.-S.; Lee, J. A Size-Selectively BiomoleculeImmobilized Nanoprobe-Based Chemiluminescent Lateral Flow Immunoassay for Detection of Avian-Origin Viruses. Anal. Chem. 2021, 93, 792-800. [CrossRef] [PubMed]

179. Bartman, M.T.; Kaidarova, Z.; Hirschkorn, D.; Sacher, R.A.; Fridey, J.; Garratty, G.; Gibble, J.; Smith, J.W.; Newman, B.; Yeo, A.E.; et al. Long-term increases in lymphocytes and platelets in human T-lymphotropic virus type II infection. Blood 2008, 112, 3995-4002. [CrossRef]

180. Wang, L.-J.; Ren, M.; Liang, L.; Zhang, C.-Y. Controllable fabrication of bio-bar codes for dendritically amplified sensing of human T-lymphotropic viruses. Chem. Sci. 2018, 9, 4942-4949. [CrossRef]

181. Yang, H.; Guo, Y.; Li, S.; Lan, G.; Jiang, Q.; Yang, X.; Fan, J.; Ali, Z.; Tang, Y.; Mou, X.; et al. Magnetic beads-based chemiluminescent assay for ultrasensitive detection of pseudorabies virus. J. Nanosci. Nanotechnol. 2014, 14, 3337-3342. [CrossRef]

182. Xiang, A.; Wei, F.; Lei, X.; Liu, Y.; Liu, Y.; Guo, Y. A simple and rapid capillary chemiluminescence immunoassay for quantitatively detecting human serum HBsAg. Eur. J. Clin. Microbiol. Infect. Dis. 2013, 32, 1557-1564. [CrossRef] [PubMed]

183. Sabouri, S.; Ghourchian, H.; Shourian, M.; Boutorabi, M. A gold nanoparticle-based immunosensor for the chemiluminescence detection of the hepatitis B surface antigen. Anal. Methods 2014, 6, 5059-5066. [CrossRef]

184. Liu, W.; Kou, G.; Dong, Y.; Zheng, Y.; Ding, Y.; Ni, W.; Wu, W.; Tang, S.; Xiong, Z.; Zhang, Y.; et al. Clinical application of Chemiluminescence Microparticle Immunoassay for SARS-CoV-2 infection diagnosis. J. Clin. Virol. 2020, 130, 104576. [CrossRef] [PubMed]

185. Boukli, N.; Le Mene, M.; Schnuriger, A.; Cuervo, N.S.; Laroche, C.; Morand-Joubert, L.; Gozlan, J. High Incidence of False-Positive Results in Patients with Acute Infections Other than COVID-19 by the Liaison SARS-CoV-2 Commercial Chemiluminescent Microparticle Immunoassay for Detection of IgG Anti-SARS-CoV-2 Antibodies. J. Clin. Microbiol. 2020, 58, e01352-20. [CrossRef]

186. Padoan, A.; Cosma, C.; Sciacovelli, L.; Faggian, D.; Plebani, M. Analytical performances of a chemiluminescence immunoassay for SARS-CoV-2 IgM/IgG and antibody kinetics. Clin. Chem. Lab. Med. 2020, 58, 1081-1088. [CrossRef]

187. Cai, X.F.; Chen, J.; Li Hu, J.; Long, Q.X.; Deng, H.J.; Liu, P.; Fan, K.; Liao, P.; Liu, B.Z.; Wu, G.C.; et al. A Peptide-Based Magnetic Chemiluminescence Enzyme Immunoassay for Serological Diagnosis of Coronavirus Disease 2019. J. Infect. Dis. 2020, 222, 189-193. [CrossRef]

188. Roda, A.; Cavalera, S.; Di Nardo, F.; Calabria, D.; Rosati, S.; Simoni, P.; Colitti, B.; Baggiani, C.; Roda, M.; Anfossi, L. Dual lateral flow optical/chemiluminescence immunosensors for the rapid detection of salivary and serum IgA in patients with COVID-19 disease. Biosens. Bioelectron. 2021, 172, 112765. [CrossRef]

189. Li, Y.; Hong, M.; Qiu, B.; Lin, Z.; Cai, Z.; Chen, Y.; Chen, G. A highly sensitive chemiluminescent metalloimmunoassay for H1N1 influenza virus detection based on a silver nanoparticle label. Chem. Commun. 2013, 49, 10563-10565. [CrossRef] 
190. Wang, X.; Ge, L.; Yu, Y.; Dong, S.; Li, F. Highly sensitive electrogenerated chemiluminescence biosensor based on hybridization chain reaction and amplification of gold nanoparticles for DNA detection. Sens. Actuators B Chem. 2015, 220, 942-948. [CrossRef]

191. Yu, H.; Kim, K.; Ma, K.; Lee, W.; Choi, J.-W.; Yun, C.-O.; Kim, D. Enhanced detection of virus particles by nanoisland-based localized surface plasmon resonance. Biosens. Bioelectron. 2013, 41, 249-255. [CrossRef]

192. Sharma, P.K.; Kumar, J.S.; Singh, V.V.; Biswas, U.; Sarkar, S.S.; Alam, S.I.; Dash, P.K.; Boopathi, M.; Ganesan, K.; Jain, R. Surface plasmon resonance sensing of Ebola virus: A biological threat. Anal. Bioanal. Chem. 2020, 412, 4101-4112. [CrossRef]

193. Bai, H.; Wang, R.; Hargis, B.; Lu, H.; Li, Y. A SPR Aptasensor for Detection of Avian Influenza Virus H5N1. Sensors 2012, 12, 12506-12518. [CrossRef] [PubMed]

194. Estmer Nilsson, C.; Abbas, S.; Bennemo, M.; Larsson, A.; Hämäläinen, M.D.; Frostell-Karlsson, Å. A novel assay for influenza virus quantification using surface plasmon resonance. Vaccine 2010, 28, 759-766. [CrossRef] [PubMed]

195. Lepage, D.; Jiménez, A.; Beauvais, J.; Dubowski, J.J. Real-time detection of influenza A virus using semiconductor nanophotonics. Light Sci. Appl. 2013, 2, e62. [CrossRef]

196. Nguyen, V.T.; Seo, H.B.; Kim, B.C.; Kim, S.K.; Song, C.S.; Gu, M.B. Highly sensitive sandwich-type SPR based detection of whole H5Nx viruses using a pair of aptamers. Biosens. Bioelectron. 2016, 86, 293-300. [CrossRef] [PubMed]

197. Omar, N.A.S.; Fen, Y.W.; Abdullah, J.; Mustapha Kamil, Y.; Daniyal, W.M.E.M.M.; Sadrolhosseini, A.R.; Mahdi, M.A. Sensitive Detection of Dengue Virus Type 2 E-Proteins Signals Using Self-Assembled Monolayers/Reduced Graphene Oxide-PAMAM Dendrimer Thin Film-SPR Optical Sensor. Sci. Rep. 2020, 10, 2374. [CrossRef] [PubMed]

198. Choi, Y.-H.; Lee, G.-Y.; Ko, H.; Chang, Y.W.; Kang, M.-J.; Pyun, J.-C. Development of SPR biosensor for the detection of human hepatitis B virus using plasma-treated parylene-N film. Biosens. Bioelectron. 2014, 56, 286-294. [CrossRef]

199. Shang, J.; Ye, G.; Shi, K.; Wan, Y.; Luo, C.; Aihara, H.; Geng, Q.; Auerbach, A.; Li, F. Structural basis of receptor recognition by SARS-CoV-2. Nature 2020, 581, 221-224. [CrossRef]

200. Liu, Y.; Huang, C.Z. One-step conjugation chemistry of DNA with highly scattered silver nanoparticles for sandwich detection of DNA. Analyst 2012, 137, 3434-3436. [CrossRef]

201. Wang, X.; Li, Y.; Wang, H.; Fu, Q.; Peng, J.; Wang, Y.; Du, J.; Zhou, Y.; Zhan, L. Gold nanorod-based localized surface plasmon resonance biosensor for sensitive detection of hepatitis B virus in buffer, blood serum and plasma. Biosens. Bioelectron. 2010, 26, 404-410. [CrossRef]

202. Xia, L.; Song, J.; Xu, R.; Liu, D.; Dong, B.; Xu, L.; Song, H. Zinc oxide inverse opal electrodes modified by glucose oxidase for electrochemical and photoelectrochemical biosensor. Biosens. Bioelectron. 2014, 59, 350-357. [CrossRef]

203. Altug, H.; Vučković, J. Polarization control and sensing with two-dimensional coupled photonic crystal microcavity arrays. Opt. Lett. 2005, 30, 982-984. [CrossRef] [PubMed]

204. Li, Q.; Zhou, S.; Zhang, T.; Zheng, B.; Tang, H. Bioinspired sensor chip for detection of miRNA-21 based on photonic crystals assisted cyclic enzymatic amplification method. Biosens. Bioelectron. 2020, 150, 111866. [CrossRef]

205. Fathi, F.; Rashidi, M.-R.; Pakchin, P.S.; Ahmadi-Kandjani, S.; Nikniazi, A. Photonic crystal based biosensors: Emerging inverse opals for biomarker detection. Talanta 2021, 221, 121615. [CrossRef] [PubMed]

206. Griol, A.; Peransi, S.; Rodrigo, M.; Hurtado, J.; Bellieres, L.; Ivanova, T.; Zurita, D.; Sánchez, C.; Recuero, S.; Hernández, A.; et al. Design and Development of Photonic Biosensors for Swine Viral Diseases Detection. Sensors 2019, 19, 3985. [CrossRef]

207. Mustapha Kamil, Y.; Abu Bakar, M.H.; Mustapa, M.A.; Yaacob, M.H.; Abidin, N.H.Z.; Syahir, A.; Lee, H.J.; Mahdi, M.A. Label-free Dengue E protein detection using a functionalized tapered optical fiber sensor. Sens. Actuators B Chem. 2018, 257, 820-828. [CrossRef]

208. Zhao, B.; Che, C.; Wang, W.; Li, N.; Cunningham, B.T. Single-step, wash-free digital immunoassay for rapid quantitative analysis of serological antibody against SARS-CoV-2 by photonic resonator absorption microscopy. Talanta 2021, 225, 122004. [CrossRef]

209. Pal, S.; Yadav, A.R.; Lifson, M.A.; Baker, J.E.; Fauchet, P.M.; Miller, B.L. Selective virus detection in complex sample matrices with photonic crystal optical cavities. Biosens. Bioelectron. 2013, 44, 229-234. [CrossRef]

210. Rippa, M.; Castagna, R.; Brandi, S.; Fusco, G.; Monini, M.; Chen, D.; Zhou, J.; Zyss, J.; Petti, L. Octupolar Plasmonic Nanosensor Based on Ordered Arrays of Triangular Au Nanopillars for Selective Rotavirus Detection. ACS Appl. Nano Mater. 2020, 3 , 4837-4844. [CrossRef] 